\title{
NIST-NOAA Survey Instrument for Business Disruption and Recovery Associated with Extreme Events:
}

\section{General Instrument Applied to the Greater Charleston, SC Small- and Medium-Sized Business Community Post-Hurricane Irma}




\title{
NIST-NOAA Survey Instrument for Business Disruption and Recovery Associated with Extreme Events:
}

\section{General Instrument Applied to the Greater Charleston, SC Small- and Medium-Sized Business Community Post-Hurricane Irma}

\author{
Jennifer F. Helgeson \\ Applied Economics Office \\ Engineering Laboratory \\ Eleanor D. Pierel \\ Kirstin Dow \\ Geography Department \\ University of South Carolina
}

This publication is available free of charge from: https://doi.org/10.6028/NIST.DCI.001

September 2020

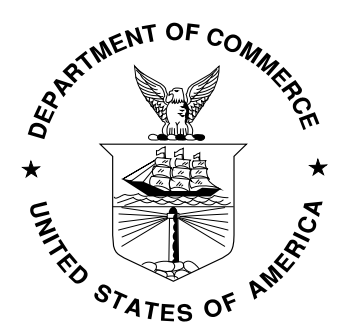

U.S. Department of Commerce Wilbur L. Ross, Jr., Secretary 
Certain commercial entities, equipment, or materials may be identified in this document in order to describe an experimental procedure or concept adequately. Such identification is not intended to imply recommendation or endorsement by the National Institute of Standards and Technology, nor is it intended to imply that the entities, materials, or equipment are necessarily the best available for the purpose.

The NIST Data Collection Instruments series include questionnaires or survey instruments, interview guides, and other structured means of collecting data. Some of these instruments are designed for human subjects research focused on households, social institutions, and businesses. The instruments are approved by both NIST Institutional Review Board (IRB) and OMB/Paperwork Reduction Act.

National Institute of Standards and Technology Data Collection Instruments 001

Natl. Inst. Stand. Technol. Data Collect. Instr. 001, 65 pages (September 2020)

This publication is available free of charge from: https://doi.org/10.6028/NIST.DCI.001 


\begin{abstract}
To gather more in-depth information about how disasters affect businesses, the National Institute of Standards and Technology (NIST) and the National Oceanic and Atmospheric Administration (NOAA) have launched a study of business disruption and recovery related to several natural disasters.

This report outlines the survey instrument used as the basis for the research designed to be conducted in partnership between the NIST Applied Economics Office (AEO) and a placebased, interdisciplinary regional research team via the NOAA Regional Integrated Sciences and Assessment (RISA) Program.

This research protocol uses a mixed-method research approach to study businesses that were impacted by Hurricane Irma in 2017 and their long-term recovery process. The approach combines both quantitative and qualitative data collection methods using both in-person and telephone surveys to obtain business disruption and recovery information from business owners and managers.
\end{abstract}

\title{
Key words
}

Adaptive capacity; built infrastructure, business recovery; community resilience; coping; extreme weather events; resilience planning; Small- and Medium-sized Enterprises (SMEs); survey instrument. 


\title{
Acknowledgements
}

The authors wish to thank all those who contributed ideas and suggestions for this report and the survey presented herein.

Special appreciation is extended to Claudia Nierenberg (NOAA) for her vision for this NISTNOAA collaboration and continued active involvement and support. Ariela Zycherman (NOAA) for her helpful review of this report and evaluation of the overarching SME research effort as it continues to develop and address COVID-19 circumstances.

Appreciation is extended to Chief Resilience Officer Mark Wilbert (City of Charleston) and his team for their time and interest in this work.

The time and information shared by all greater Charleston, SC SME owner/manager respondents in the pilot phase of this survey is deeply appreciated. There would be no survey or research project without them. Additional thanks to Scott Cave (Atlantic Business Continuity Services) and Jack Smith (Nelson Mullins) for reviewing the survey from the perspective of the Charleston business community. Thanks to Norman Levine (College of Charleston) for his willingness to share maps and data to inform the sampling.

Sincere appreciation to the research assistants involved in this effort: Charlton Brownell (College of Charleston), Chelsea Diedrich (College of Charleston), Liz McQuain (College of Charleston), Haley Schanne (College of Charleston), and Kristin Sherlock (College of Charleston).

\author{
Author Information \\ Jennifer F. Helgeson, Ph.D. \\ Research Economist, Applied Economics Office, Engineering Laboratory \\ National Institute of Standards and Technology \\ 100 Bureau Drive, Mailstop 8603 \\ Gaithersburg, MD 20899-8603 \\ Tel.: 301-975-6133 \\ Email: jennifer.helgeson@nist.gov
}


Eleanor D. Pierel, M.S., PhD Candidate

Department of Geography

University of South Carolina

709 Bull Street

Columbia, SC 29208

Tel.: 717-892-4350

Email: eleanord@email.sc.edu

Kirstin Dow, Ph.D.

Professor

Department of Geography

University of South Carolina

709 Bull Street

Columbia, SC 29208

Tel.: 803-777-2482

Email: KDow@sc.edu 


\section{Table of Contents}

1. Executive Summary............................................................................................................ 7

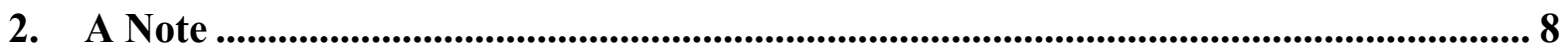

3. Background and Motivation...................................................................................... 9

4. Relevance and Objectives ........................................................................................ 10

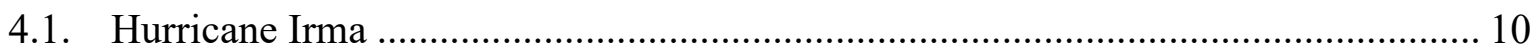

4.2. Importance of considering SME recovery ........................................................... 10

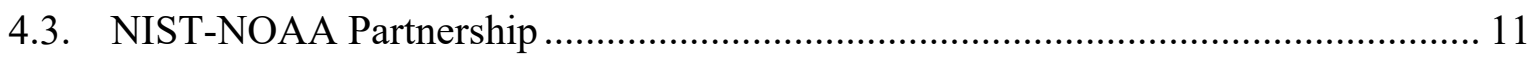

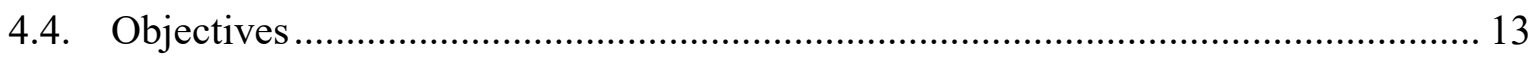

5. Scope and Framing ...................................................................................................... 13

5.1. SME size and ownership structure .................................................................. 14

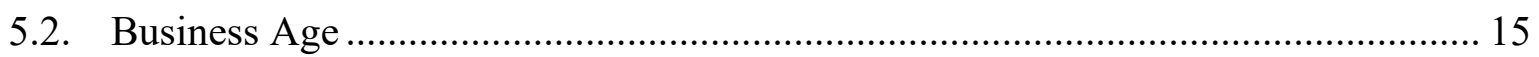

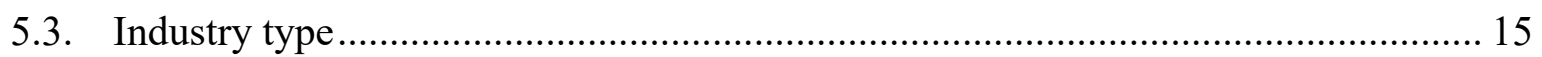

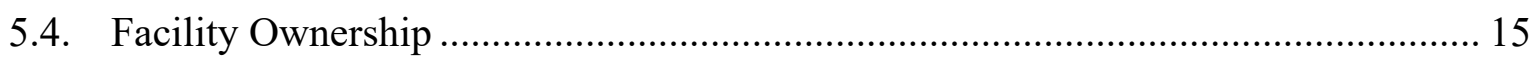

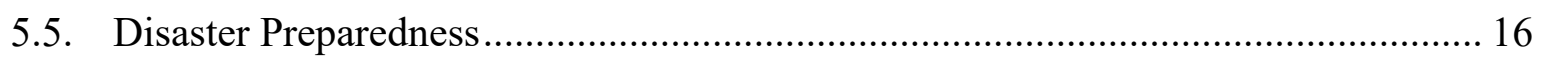

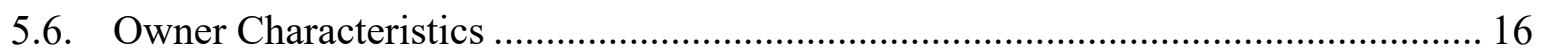

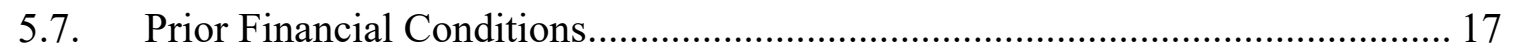

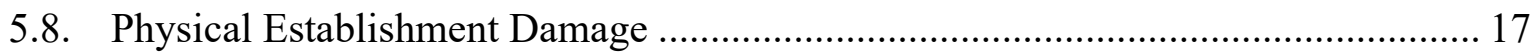

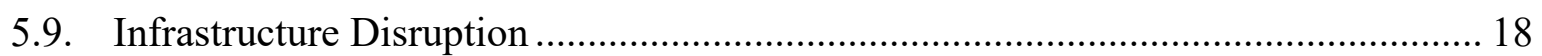

5.10. Changing Economic Conditions/Context ........................................................... 18

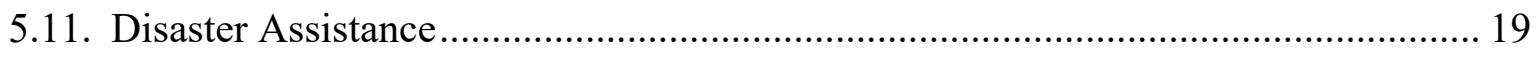

6. Sampling Procedures............................................................................................................ 20

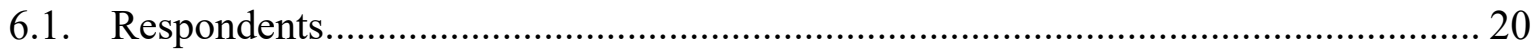

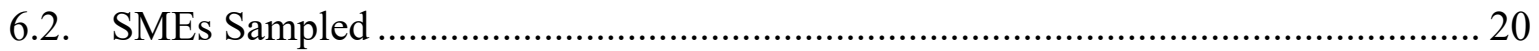

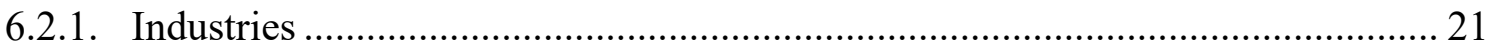

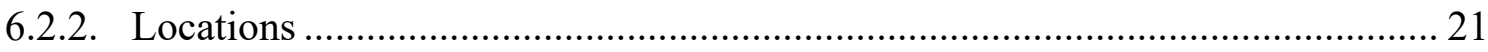

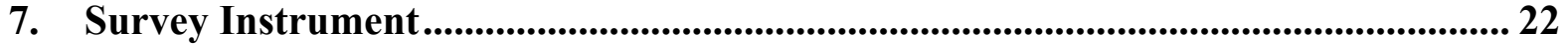

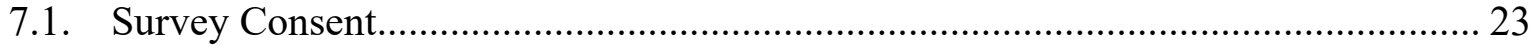

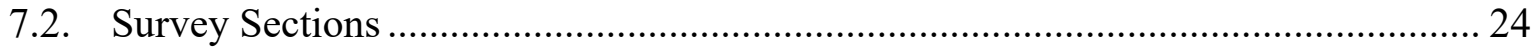

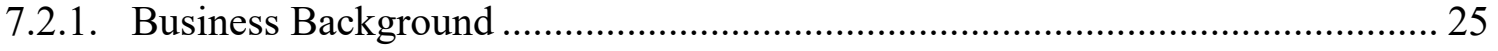

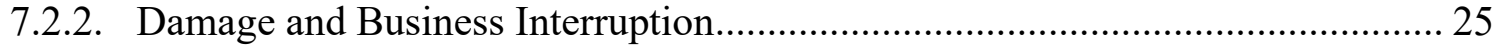

7.2.3. Employee-related Questions......................................................................... 29

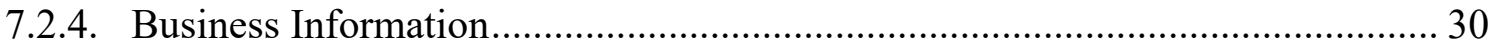




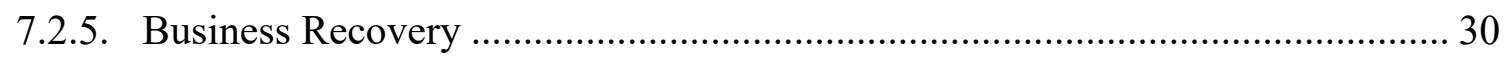

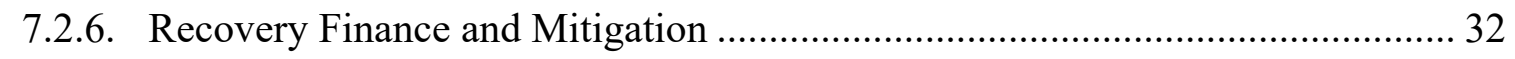

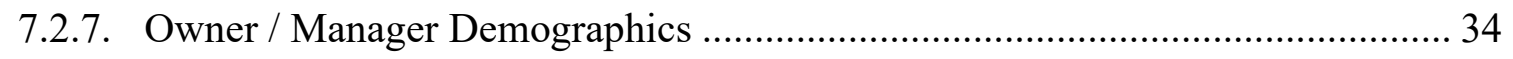

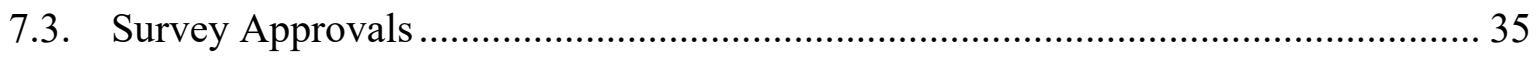

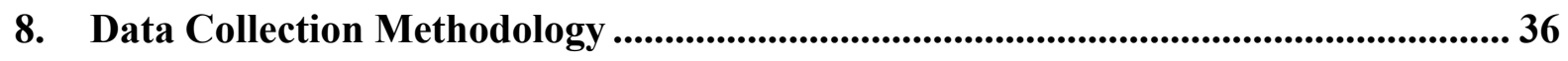

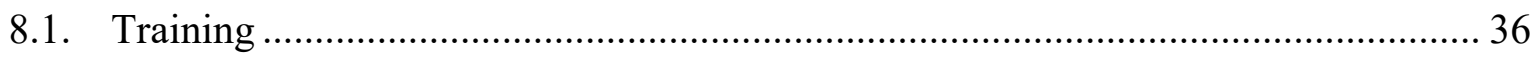

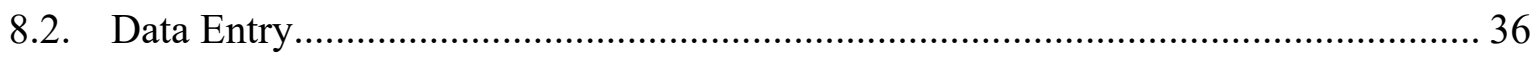

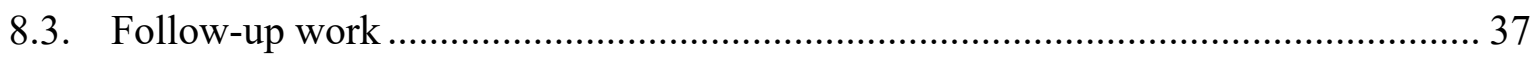

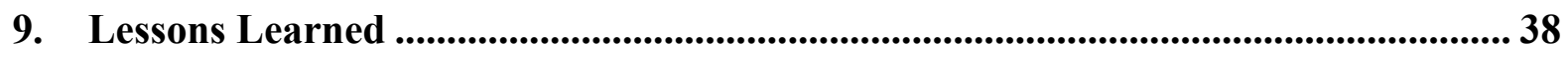

10. Future Work ......................................................................................................................... 39

Appendix A - Complete Survey (Note Version)....................................................................... 41

Appendix B - Consent Script................................................................................................... 51

Appendix C - Descriptions of Business Damage States ..................................................... 53

Appendix D - Descriptions of Business Mitigation Activities - categories and sub-

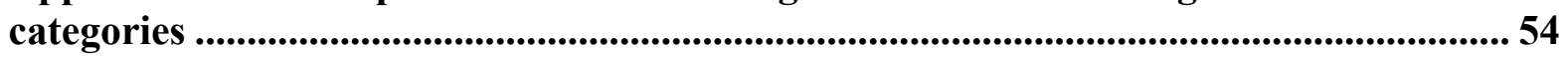

Appendix E - Business Communication Tracking ............................................................. 56

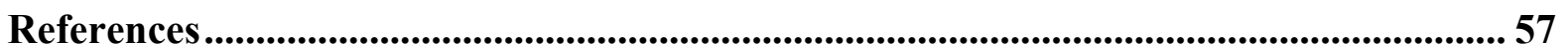

\section{List of Tables}

Table 1. Sample vs. Respondent Industry Composition ....................................................... 21

Table 2. Detailed damage descriptions for business building components ........................... 53

\section{List of Figures}

Figure 1. Business locations overlaid on modeled Hurricane Irma flood map....................... 22

Figure 2. Business Interruption and Recovery schematic...................................................... 23

Figure 3. Leave-behind postcard with information about the survey .................................... 38 


\section{Glossary}

AEO Applied Economics Office

ASCE American Society of Civil Engineers

CISA Carolinas Integrated Sciences and Assessments

CITI Collaborative Institutional Training Initiative

COE Center of Excellence

COVID-19 Coronavirus Disease 2019

EL Engineering Laboratory

EWE extreme weather event

NCEI National Centers for Environmental Information

NIST National institute of Standards and Technology

NOAA National Oceanic and Atmospheric Association

RISA Regional Integrated Sciences and Assessments

SME Small- and Medium-sized Enterprise

SPARC Support to Promote Advancement of Research and Creativity 


\section{Executive Summary}

To gather more in-depth information about how disasters affect businesses, and business resilience capacity in the face of repeated losses, the National Institute of Standards and Technology (NIST) and the National Oceanic and Atmospheric Administration (NOAA) have launched a study of business disruption and recovery related to several natural disasters.

This report outlines the initial implementation of a survey instrument used as the basis for the research designed to be conducted in partnership between the NIST Applied Economics Office (AEO) and a set of place-based, interdisciplinary regional research teams. These teams are part of the NOAA-funded Regional Integrated Sciences and Assessments (RISA) Program. The initial location, that is the focus of this report, is the greater Charleston, South Carolina area conducted with the Carolinas Regional Integrated Sciences and Assessments (CISA), based in Columbia, South Carolina.

This research protocol uses a mixed-method research approach to study businesses that were impacted by Hurricane Irma in 2017 and their long-term recovery process. The approach combines both quantitative and qualitative data collection methods using both in-person and telephone surveys to obtain business disruption and recovery information from business owners and managers. This survey instrument assesses the perceptions and behavior of the owners/managers throughout the recovery process. The instrument is designed to explore operational interruptions experienced by the businesses, disaster recovery, financial stability, mitigation behaviors, preparedness behaviors, and overall risk-perceptions toward hazardous impacts. This tool provides suggested best practice to obtain a general assessment of how for-profit organizations are recovering from a large-scale disruptive event that affects both the built environment and the social functions of a community. In addition, the tool provides a set of questions that addresses covariate weather and climate extremes, such as high tide events.

Using this instrument, we were able to obtain a general assessment of how organizations are recovering from Hurricane Irma 18 to 24 months after the event in the Charleston, SC area. The instrument may be used in its entirety, as modules, or through the selection of specific questions. The instrument is applicable to survey for-profit organizations and can be altered to address notfor-profit organizations. 
This publication provides a description of the methods used to design and conduct the survey instrument as well as suggested sampling procedures. This research was designed such that disaster professionals, risk management experts, and academic researchers can better understand and support business owners and managers in disaster preparation and planning as well as throughout the recovery process in their community.

\section{A Note}

The intention of this collaborative project across Department of Commerce agencies and including local academic researchers was to provide longitudinal data through place-based research. However, Hurricane Dorian disturbed data collection efforts during September 2019.

Hurricane Dorian impacted the coast of South Carolina just after the extended pilot study using this survey instrument. Both Irma and Dorian had similar impacts in Charleston as neither made landfall in the area. Hurricane Irma caused gusts up to $65 \mathrm{mph}(105 \mathrm{kph}), 6$ to 8 inches (15.3 to $20.3 \mathrm{~cm}$ ) of rain, and 3.8 to 5 feet (1.2 to $1.5 \mathrm{~m}$ ) of storm surge (National Weather Service, 2017). Hurricane Dorian caused gusts up to $80 \mathrm{mph}(129 \mathrm{kph}), 6$ to 8 inches $(15.3$ to $20.3 \mathrm{~cm}$ ) of rain, and 3 to 3.5 feet (0.9-1.1 m) of storm surge (National Weather Service, 2019). Many businesses closed for both events, though there was only a formal evacuation declaration for Hurricane Dorian. Due to greater salience, the Online Survey and Longitudinal Survey 2 was planned to focus on participants' experiences during Hurricane Dorian and 2019 high tide flooding (Fanta et al., 2019).

Just as continued efforts incorporating Hurricane Dorian impacts and recovery was launched the National Emergency for the COVID-19 pandemic was announced in March 2020. This pandemic has impacted the ability for longitudinal data collection to continue, especially as inperson data collection has not been possible while social distancing measures are in place. However, lessons learned from the survey presented in this report have informed work on compound risks and complex events from the combination of COVID-19 disruptions and potential natural hazard impacts. In particular, a Ph.D. dissertation study is currently underway and is supported by the University of South Carolina's Support to Promote Advancement of Research 
and Creativity (SPARC). ${ }^{1}$ Furthermore, a national-level survey of SMEs facing natural disasters during the COVID-19 pandemic has been undertaken by NIST and NOAA's CPO (Climate Program Office) (Helgeson et al., 2020).

\section{Background and Motivation}

The National Centers for Environmental Information (NCEI), within NOAA, estimates that there have been 218 natural weather disaster events, each resulting in at least $\$ 1$ billion in damage and economic losses in the U.S. from 1970 to October 2017 (American Society of Civil Engineers, 2014; 2016). An increase in direct (insured) capital losses from such events is documented; however, specific effects on businesses, especially Small- and Medium-sized Enterprises (SMEs), is less well-documented. In particular, enterprise-level impacts, especially indirect losses from hazards - both idiosyncratic and covariate disasters that derive from extreme weather and climatic events - is less well-developed in the literature.

SMEs contribute significantly to local economic development and there is evidence that SME recovery may impact household recovery and greater community resilience (Morrison et al., 2003; Schaer et al., 2018; Watson et al., 2020). SMEs have a significant role within a given community both pre- and post-disaster; they can help ensure continued access to employment and ensure that a community's tax base remains constant (e.g., Tierney, 2007; Xiao and Drucker, 2013). SMEs can also act as sources of critical information and support during times of shocks and help a given community navigate persistent stressors as well; they can provide access to critical goods and services post-disaster and help maintain emotional wellbeing. However, SMEs tend to be more vulnerable than larger businesses to disruptions due to lower cash reserves, geographic limitations, limited capacity to access disaster-related aid (e.g., Corey and Deitch 2011; Dahlhamer and Tierney, 1998; Runyan 2006).

Though the business sector in general can help the community in the time of impact and recovery from extreme weather event(s), SMEs often experience post-disaster impacts that are similar to those felt by other sectors of society within a community (e.g., Schrank et al., 2013). For instance, post-disaster impact, SMEs are often faced with disruption to their infrastructure, supporting services, utility operations, required supplies, and services (Marshall et al., 2015;

\footnotetext{
${ }^{1}$ SPARC Graduate Research Award Project 80003619. University of South Carolina, Office of the Vice President for Research (May 1, 2020 - July 31, 2021). PIs: K. Dow and E.D. Pierel (order based on requirements).
} 
Tierney, 1997; Webb et al., 2000). In addition, many often lose their entire inventories and experience great damage to their building structures that prevent them from reopening quickly (ibid.). Additionally, there is evidence of loss of both a supply of labor and a supply on demand by consumers on SMEs when households in the community are affected (e.g., Watson et al., 2020).

\section{Relevance and Objectives}

\subsection{Hurricane Irma}

The 2017 Atlantic hurricane season was one of the most intense and active seasons the United States has experienced (NOAA, 2017); there were 17 named storms, 10 hurricanes, of which 6 were ranked as a category 3 to 5 on the Saffir-Simpson scale (ibid.). The storms that had the greatest impact on the United States were Harvey and Irma, causing the United States close to $\$ 300$ billion in damages (NOAA, 2019).

Hurricane Irma initially made landfall in Cudjoe Key, Florida on September 10, 2017 and then traveled up the coastline, inland to the west. The storm dropped an average of 15.91 inches (40.41 $\mathrm{cm}$ ) of rain across five states: Florida, Georgia, South Carolina, North Carolina, and Alabama (Cangialosi et al., 2018). The Category three hurricane produced winds up to 177 miles per hour. The total damages in the United States occurring as a result of Hurricane Irma were approximately $\$ 50$ billion according to NOAA (2018). This 500-year storm affected over 1.2 million people through utility loss and 47 lives were reported lost (ibid.). Rain water from the hurricane led to major flooding impacting the entire region.

Repeated experiences with hurricane and high tide flooding in Charleston, $\mathrm{SC}$ affords a unique opportunity to expand understanding of the role of SMEs in community resilience, both informing theory of resilience and gathering valuable lessons for other communities not yet experiencing this magnitude of repetitive stress.

\subsection{Importance of considering SME recovery}

SMEs are socially and economically important to society. SMEs contribute significantly to local economic development and job creation (Morrison et al., 2003; Schaer et al., 2018). They are

invested in their communities and improve local median household income, reduce poverty, and decrease income inequality (Blanchard et al., 2012; Lyson et al., 2001; Tolbert et al., 1998). Almost half of the U.S. workforce is employed by an SME and $75 \%$ of new jobs come from SMEs (SBA, 
2019). They are often referred to as the "lifeblood of the U.S. economy" and account for about $44 \%$ of U.S. economic activities (ibid.).

Yet, SMEs tend to display vulnerability in facing disaster events, ultimately resulting in high rates of business failure. Small businesses have a higher chance of closure post-disaster impact because they often experience a larger proportionate loss as compared to larger businesses (Schrank et al., 2013; Tierney, 1997). According to FEMA statistics, $40 \%$ of businesses that experience a natural disaster do not survive and $90 \%$ of businesses that are closed for more than five days after a disaster do not survive a year (Marshall et. al., 2015).

The ability of SMEs to address the challenges that come with disasters, especially those events that affect built infrastructure and the social functions it supports, is constrained due to limited access to financial resources and capital (e.g., Alesch et al., 2001; Kroll et al., 1991; Zhang et al., 2009). It is therefore pertinent to investigate unique SME behavior, coping skills, and resilience in addressing direct effects of extreme weather and climate events, as well as the various indirect economic effects of extreme weather events.

It is recognized that the SME sector overall poses various challenges for implementing policies and the transfer of good practice in disaster resilience planning and mitigation (e.g., Cavanaugh, 2000; Chang and Rose, 2012). However, these limitations likely relate back to the fact that SMEs tend to operate close to the margins; thus, strategic horizons and organizational capabilities do not allow sufficient organizational flexibility to conduct activities outside of their main business functions. Thus, understanding the SME resilience agenda is of strategic importance to greater community resilience through mitigating measures against extreme weather events over time. For example, understanding more about how SMEs' conceptualize the appropriate degree of association of mitigation measures with the mainstream business activities will help inform effective engagement, identification of SME coping strategies, roles for intermediaries, and the preparation of interface toolkits and other support materials and resources.

\subsection{NIST-NOAA Partnership}

NIST and NOAA, both under the umbrella of the U.S. Department of Commerce, share overlapping and complementary Federal Community Resilience-related missions. NIST is a physical sciences laboratory and a non-regulatory agency. NIST's Engineering Laboratory is focused upon the engineered environment that supports socio-economic functions. Members of 
the NIST Applied Economics Office (AEO) support the EL's Community Resilience Research Program. NIST's mission statement includes a call to promote U.S. innovation and industrial competitiveness by advancing measurement science, standards, and technology for engineered systems in ways that enhance economic security and improves quality of life. ${ }^{2}$ In particular, NIST researchers collaborate with the Community Resilience Center of Excellence (COE), which is led by Colorado State University in partnership with 12 universities, to accelerate development of system-level models and associated databases to support community resilience decision-making. Some of the core structure of the SME business recovery survey introduced herein arises from SME recovery survey data collection undertaken through the collaborative work of NIST and the COE.

NOAA's mission is to understand, predict and communicate changes in climate, weather, oceans and coasts and to conserve and manage coastal and marine resources. The NOAA mission statement includes a call for "products and services that support economic vitality and affect more than one-third of America's gross domestic product."3 NOAA's scientists throughout its laboratories and cooperative institutes, and with partners in the universities and state, local, and Tribal entities, undertake cutting-edge research to support weather, climate, ocean and coastal services and provide citizens, planners, emergency managers and other decision makers with relevant and reliable information. NOAA's assets include prominent external research and engagement networks, including the RISA network that serves as the place-based, community focused research partner in this study. NOAA's research and engagement networks also include the Sea Grant Program and the National Estuarine Research Reserves.

This research, conducted in partnership across DOC agencies and their regional research networks, provides a method for data collection to advance the measurement science of resilience planning for natural hazards - on both the levels of the individual business and the community. Currently, disaster-related loss (and damage) estimates are available, although they tend to focus on direct loss and are reported at aggregated levels. These estimates often fail to consider downstream, indirect, cumulative, and sustained effects, such as business interruption and loss of capacity on the individual business-level. These impacts can be large and lasting, and can therefore have a significant effect on the short- and long-term stability of a local or regional economy.

\footnotetext{
${ }^{2}$ See: https://www.nist.gov/about-nist

${ }^{3}$ See: https://www.noaa.gov/about-our-agency
} 
The short-term recovery period following the 2017 hurricane season in the U.S. motivated NIST and NOAA to work together to develop a research protocol for assessing the mid-term recovery of areas affected by these events. The goal of this effort was to follow mid- and longterm recovery of SMEs in the locations surveyed. This remains the goal; however, the mode and methods of surveying have changed as long-term recovery from the 2017 hurricane season was affected by additional extreme weather events as well as the COVID-19 pandemic. While challenging to this study, these changes further emphasize the imperative of resilience planning for natural hazards.

This effort contributes to the business communities in the locations surveyed, wider community planning in those locations, the research and service communities in those locations, evaluation and valuation of NOAA applied research investments, and the development of the NIST Coastal Community Resilience Program.

\subsection{Objectives}

The identified objectives of this NIST-NOAA project as reflected in the developed survey instrument are to:

1. Gain a better understanding of the nature of impacts experienced by SMEs;

2. Understand the experience of business owners and managers through different kinds of extremes as well as how their perceptions of risk may change between events;

3. Gather data on the specific physical and financial effects, including the extent to which early warning information was a factor in preparation; and

4. Provide an analysis of the risk profiles of small business owners in vulnerable areas and the resources they currently have access to that support response, recovery, and continuity.

\section{Scope and Framing}

Much of disaster research focused at the community level has looked at the immediate impact of a disaster on households (e.g., Tierney, 1997; Xiao and Van Zandt, 2011). Limited research is expanding to include the impact of disasters on SMEs at the individual firm-level and the 
connection between households as a source of demand for goods offered by SMEs and a source of supply for SME labor (e.g., Watson et al., 2020).

Research on business recovery in the United States at the individual firm level tends to focus on long-term recovery (e.g., Marshall et al., 2015). Fewer studies focus on short-term business outcomes (e.g., Dahlhamer and Tierney, 1996; Xiao and Van Zandt, 2012). Marshall and Shrank (2014) identified the need for longitudinal, comprehensive studies of business recovery. Therefore, it is important to study the disruption and recovery of these organizations in a detailed manner and when possible longitudinally. This section provides a truncated review of the literature in the space of SME disaster resilience and recovery to date, findings of which were leveraged in development of the survey instrument provided.

It should be noted that the SME characteristics, both those that are independent of a disaster occurrence (e.g., size and enterprise age) and those that relate more directly to disaster planning (e.g., lack formal disaster planning), are rarely mutually exclusive in nature. We have attempted to group these by general theme in this brief review.

\subsection{SME size and ownership structure}

SME size has been repeatedly shown to be a statistically significant indicator of business survival post-disaster (Alesch et al. 2001; Basker and Miranda, 2018; Dahlhamer and Tierney, 1998; Tierney, 1997) with evidence that smaller firms are more sensitive in general to economic downturns in the normal business cycle (Fort et al., 2013). Smaller businesses (in terms of number of staff and enterprise earnings) hold fewer cash reserves, and are heavily reliant upon local customers. Furthermore, smaller businesses are not in a financial position to actively take on what may be viewed as elective mitigation measures, such as insurance against hazards and business interruption (Zhang et al., 2009). Much of the research in this space leveraged firm size as a proxy for access to resources (e.g., Fort et al., 2013) due to the general finding that that larger firms generally have more resources and better financing available, as well as greater access to government programs (Aldrisch and Auster, 1986).

Legal form of ownership also typically influences preparedness levels (Barman et al, 2012), but this finding is inconsistent across the literature (e.g., Webb et al., 2000). A single business location operating as part of a national chain in an area vulnerable to disaster may lose the same 
level of resources as other small businesses in the area; however, the business may be able to rely upon resources from the national operations of the chain to which it belongs (Zolin and Kropp, 2007).

\subsection{Business Age}

The length of time an SME has been in business routinely is a fair predictor of business failure/survival over longer timeframes, whereas it can be a poor predictor of short-term failure (Marshall et al., 2015). However, it is unclear whether there is a threshold of time post-disaster after which an SME is more likely to remain in business if they have survived to the threshold. Dahlhamer and Tierney (1996) found there to be a "liability of newness" in their analysis of businesses after the Northridge earthquake. Newer firms tend to react with greater sensitivity to changes in the economic environment (e.g., Fort et al., 2013).

\subsection{Industry type}

SME financial recovery varies widely based on industry type and physical location; however, results are not consistent across the literature (Corey and Deitch, 2011). The retail sector is often found to be the most vulnerable to survival (e.g., Webb et al., 2002; Wasileski et al., 2011). The manufacturing and construction industries tend to be relatively most resilient (e.g., Corey and Deitch, 2011). Alesch et al. (2001) find that the level of criticality of the main product offered by a firm is a factor in recovery; thus, supplies for immediate consumption, such as food and medications are purchases that cannot be delayed by an individual in need to these items. Closing a retail business for even a short time can provide a distinct competitive advantage to competing

firms. Furthermore, industry type largely influences the ability of a business to conduct sales and provide services remotely, either from an alternative location or through online sales and remote delivery of services.

\subsection{Facility Ownership}

The form of ownership of the physical structure from which a business operates regarding leasing versus ownership has not been shown to have a significant relationship to recovery (e.g., 
Asgary et al., 2012; Wasileski et al., 2011). There is evidence that home-based businesses present a unique form of ownership. Dahlhamer and D'Souza (1995) indicate that homeowners tend to prepare more for disaster than do renters. This may be in part due to the fact that renters do not have as much agency and motivation as do owners to alter property to address mitigation and adaptation to potential disasters.

\subsection{Disaster Preparedness}

It should be noted that disaster preparation is a wide space of inquiry and the option sets are difficult to bound. Some studies have found short-term disaster preparation to not be a significant predictor of business survival and recovery trajectories (e.g., Webb et al., 2002; Marshall et al., 2015). Not surprisingly, the type and extent of disaster preparation tends to be a function of business size; larger firms frequently have dedicated disaster and continuity planning staff (Asgary et al., 2012). However, off-site disaster effects that influence the functionality of a business, such as infrastructure disruptions, are often not considered and well outside the control of a given business (Webb et al., 2000).

\subsection{Owner Characteristics}

Business owner characteristics, such as gender and race, have been shown to have some impact on recovery post-disaster. Marshall et al. (2015) found that female, non-Caucasian owned firms, excluding Asian-owned firms, tended to lag behind male, Caucasian-owned firms in terms of employment growth and survival. Additionally, in their study post-Hurricane Katrina, female owned businesses were also more likely to close permanently after reopening. Webb et al. (2002) found gender to be a non-factor in recovery.

There is a great deal of research on the role of gender in risk taking behavior; however, the role of gender on business recovery post-event may be affected by traditional views of gender roles (Dash et al., 2007). It is also possible that female-dominated industries align with those that are more vulnerable post-disaster; this is suggested in Enarson's (2010) analysis of the decreased presence of women in the workforce post-Hurricane Katrina.

The business owner's familial and household circumstances have been shown to have some influence on business recovery. Alesch et al. (2001) notes that family can have a negative effect; 
in the wake of a disaster, business owners may be forced to deal simultaneously with family issues, such as loss or injury, and business-related issues.

The skill of the business owner can also play a role in survival; in particular, research in this space looks at the ability of an owner to persevere following a disaster. Niehm et al. (2015) found that owner resilience was not a significant predictor of business closure immediately after Hurricane Katrina; however, it was a significant negative predictor of business closure a year postdisaster. Experience with previous disasters or closures has been shown to be a significant benefit to business recovery (Asgary et al., 2012; Marshall et al., 2015).

\subsection{Prior Financial Conditions}

The financial situation of a business pre-disaster was found to be a significant factor in predicting business short-term recovery (i.e., immediately after a disaster) (Dahlhamer and Tierney 1998, Marshall et al., 2015). However, Tierney and Webb (2001) find that a business' pre-disaster "financial health" was not a significant indicator of long-term recovery. Eggers (2020) notes that SMEs face a "liability of smallness" and disasters create additional liquidity issues for these businesses.

\subsection{Physical Establishment Damage}

Wasileski et al. (2011) found that establishment damage was a significant predictor of business closure in cases when damage disrupted business operation. Permit issues were shown to complicate reconstruction efforts after the 2003 Cedar Fire in San Diego County, California (Vigil, 2004). Yet, in some studies, physical damage to an establishment, its contents, and/or machinery have been found to not be a strong predictor of business recovery (Alesch et al., 2001, Chang and Falit-Baiamonte, 2002).

Tierney (2007) noted that, while damage was an important consideration, many of the challenges facing buildings post-disaster are independent of the amount of physical damage to the structure. If damage is insignificant in terms of predicating business demise, then it may be the case that other effects of the disaster are more pertinent, and not necessarily that direct physical damage plays no part. Chang and Falit-Baiamonte (2002) found that physical damage may not even be a significant predictor of business losses. Alesch et al. (2001) found a significant positive 
correlation between asset loss without insurance and business demise; thus, while not a guarantee of survival, insurance appears to protect equity and washes out the effect of physical damage.

\subsection{Infrastructure Disruption}

Pertinent post-disaster recovery factors include the level of disruption to operations experienced by the business. In short, localized damage can have a widespread effect on businesses if the damaged area provides infrastructure access (Zhang et al. 2009) and many businesses are not aware of how much they depend on regional infrastructure (Tierney, 2007). Obvious interruptions arise from being cut-off from services, such as transportation, electricity, or water. Other disruptions include the difficulty sending and receiving shipping, and disruptions to employee or customer access to the business itself. Even if an SME is physically undamaged, the lack of employees due to personal damages or evacuations may impede the SME's ability to open. When an SME closes for a longer period than surrounding businesses, they may also lose employees who depend on gratuity (e.g. service workers) and ultimately experience a decreased capacity more long-term (Webb et al., 2000). Webb et al. (2002) found that the length of business closure and amount of disruptive damage were significant indicators of business demise, especially the duration of closure of the business for the aftermath of both the Loma Prieta earthquake and Hurricane Andrew. Infrastructure interruptions occur in the larger context of the disaster effected region and customers may not be able to reach open businesses due to their own difficulties with infrastructure (e.g., transportations disruptions).

\subsection{Changing Economic Conditions/Context}

One of the major issues that arises after a disaster for recovering businesses is the potential for substantial and lasting economics changes in the region. For example, Chang and FalitBaiamonte (2002) found that the conditions of the neighborhood were an influential factor in business recovery rates and were more predictive than physical damage to the establishment. Chang (2010) found that following the 1995 Kobe earthquake, population shifts and reduced port activity exacerbated pre-disaster trends. Alesch et al. (2001) found that a disaster often accelerated already occurring trends; furthermore, disruptions led to customers finding substitutes for affected businesses and these new patterns of business were maintained even after affected businesses 
returned to normal operational levels. Corey and Deitch (2011) found a significant positive correlation between the loss of customer base and business failure following Hurricane Katrina.

Additionally, employees may move away from the region post-disaster or otherwise be unable to work due to death, injury, loss of home, or loss of transportation, among other reasons (Tierney, 2007; Watson et al., 2020). Corey and Deitch (2011) found a significant negative correlation between staffing issues and business survival. Asgary et al. (2012) found that staff engagement during recovery to be a significant correlated with reduced business recovery time.

\subsection{Disaster Assistance}

Businesses may mitigate the effects of a disaster through monetary aid, which is provided through loans from the Small Business Administration (SBA). In the case of SMEs, Webb et al. (2002) found no significant relationship between the use of post-disaster assistance and long-term recovery outcomes; they attribute this to the fact that businesses typically have to rely on loans, as opposed to grants, for recovery efforts. In the case of Hurricane Katrina, the SBA loan program, was considered inefficient by some (Runyan, 2006; Corey and Deitch, 2011). Businesses that had the documentation required by the SBA to apply for a loan felt that dispersal was too slow to impact recovery (ibid.) ${ }^{4}$.

Considering how dependent most communities are on governmental services both pre- and post-disaster, its role in the economic recovery of a community cannot be ignored (Tierney, 2007). Haynes et al. (2019) found that family-owned businesses that received SBA loans were more likely to survive. However, Meeks (2019) found that there are limited paths for financing disaster recovery. Insured small businesses have more options while uninsured businesses must turn to subsidized loans and increasing debt. Disaster relief loans cannot be used to accrue new investments and can leave businesses with limited means of increasing revenue to meet the increase in interest payments. There are also indications that there are unmet needs for financial support post-disaster (ibid.).

Connectivity of the surrounding community can also impact the demise of small businesses. Torres et al. (2019) found that existing social capital prior to a disaster supported SME resilience and recovery through increased institutional assistance.

\footnotetext{
${ }^{4}$ The SBA requires three years of previous tax returns in order to file for a loan. However, for some disaster types, businesses loss all financial records; such was the case frequently as a result of the flooding due to the hurricane.
} 


\section{Sampling Procedures}

\subsection{Respondents}

The sampling unit was the SME with the representative agent being either an owner or manager of the SME. Previous research suggests that interviewing owners and managers provides the appropriate level of analysis to understand business culture; however, selecting this group of respondents relies upon the belief that there is reasonable interorganizational communication (e.g., knowledge of employees missing work due to flood impacts) (e.g., Augier and Teece, 2009; Grinyer and Spender, 1979; Schindehutte and Morris, 2001).

The definition of an SME used for purposes of this survey was one that employees no more than 500 employees at a single location. The SBA classifies SMEs according to ownership structure, number of employees, earnings, and industry type. The relative number of employees by which an SME is defined as such is relative to the industry classification by North American Industry Classification System (NAICS) code among other attributes. ${ }^{5}$

Though this specific application of the survey was SMEs, the generalized version is appropriate for applicable across SMEs of larger size. Additionally, the subset of SMEs, smalland medium-sized manufacturers (SMMs), were included in the sample. However, a survey focused upon that set of respondents in more detail and greater number would likely require greater inclusion of questions focused around supply chain issues.

\subsection{SMEs Sampled}

Due to the common constrains of SME disaster research such as demise and business tracking, previous studies have used convenience or representative samples, as opposed to a randomized sampling strategy (e.g., Corey and Deitch, 2011; Lam et al., 2012; LeSage et al., 2011). This study used a stratified random sampling technique of SMEs within the geographic area flooded by Hurricane Irma for initial sample selection.

The business location data were drawn from the Reference USA business dataset. This dataset is updated approximately once a year through telephone conducted by InfoGroup (2018).

\footnotetext{
${ }^{5}$ Pursuant to 61 FR 3286, Jan. 31, 1996, as amended at 67 FR 3045, Jan. 23, 2002; 82 FR 25506, June 2, 2017. https://www.sba.gov/federalcontracting/contracting-guide/size-standards
} 
Due to concerns about identifiable and sensitive information, medical offices and schools were removed. Any non-profits and government offices were also removed using their NAICS codes.

Out of the 915 remaining businesses with fewer than 500 employees, 457 were selected through stratified random sampling by industry and location. One hundred and two businesses were contacted for the pilot study with a response rate of $59 \%(n=60) .^{6}$

\subsubsection{Industries}

A stratified random sampling method was employed to maintain a representative sample of the area's industry profile (Table 1). There was a bias toward Retail Trade and Accommodation and Food Services. This is likely due to the in-person survey technique. The researchers found that in-person surveys were more easily completed at businesses with public store fronts that did not require an appointment.

Table 1. Sample vs. Respondent Industry Composition

\begin{tabular}{|l|r|r|}
\hline NAICS Category & Sample \% & Respondent \% \\
\hline Mining & 0.2 & 0.0 \\
\hline Construction & 4.6 & 1.7 \\
\hline Manufacturing & 0.7 & 0.0 \\
\hline Wholesale Trade & 1.0 & 1.7 \\
\hline Retail Trade & 16.5 & 23.7 \\
\hline Transportation and Warehousing & 4.1 & 1.7 \\
\hline Information & 2.2 & 1.7 \\
\hline Finance and Insurance & 7.5 & 5.1 \\
\hline Real Estate Rental and Leasing & 9.2 & 1.7 \\
\hline Professional, Scientific, and Technical Services & 20.6 & 5.1 \\
\hline Administrative and Support and Waste & & \\
Management and Remediation Services & 7.0 & 5.1 \\
\hline Arts, Entertainment, and Recreation & 5.8 & 11.9 \\
\hline Accommodation and Food Services & 20.6 & 32.2 \\
\hline Other Services (except Public Administration) & 6.1 & 8.5 \\
\hline
\end{tabular}

\subsubsection{Locations}

\footnotetext{
${ }^{6}$ Of the respondents, 53 businesses had fewer than 50 employees and 37 had fewer than 10 employees. The high percentage of microbusinesses in this research makes it unique in comparison to previous SME studies.
} 
The sample focused primarily on the City of Charleston with the addition of select suburbs The City of Charleston, Daniel Island, Folly Beach, Isle of Palms, Mt. Pleasant, North Charleston, and Sullivan's Island were selected by ZIP code. These suburbs were chosen due to the identification of flooding concerns by local officials.

Only businesses that were within the geographic areas flooded by Hurricane Irma were included in the stratified random sampling (Figure 1). Researchers from the College of Charleston provided a modeled flood map for the hurricane. If a business was no longer open or refused the survey, the business directly to the left of the store front was contacted.

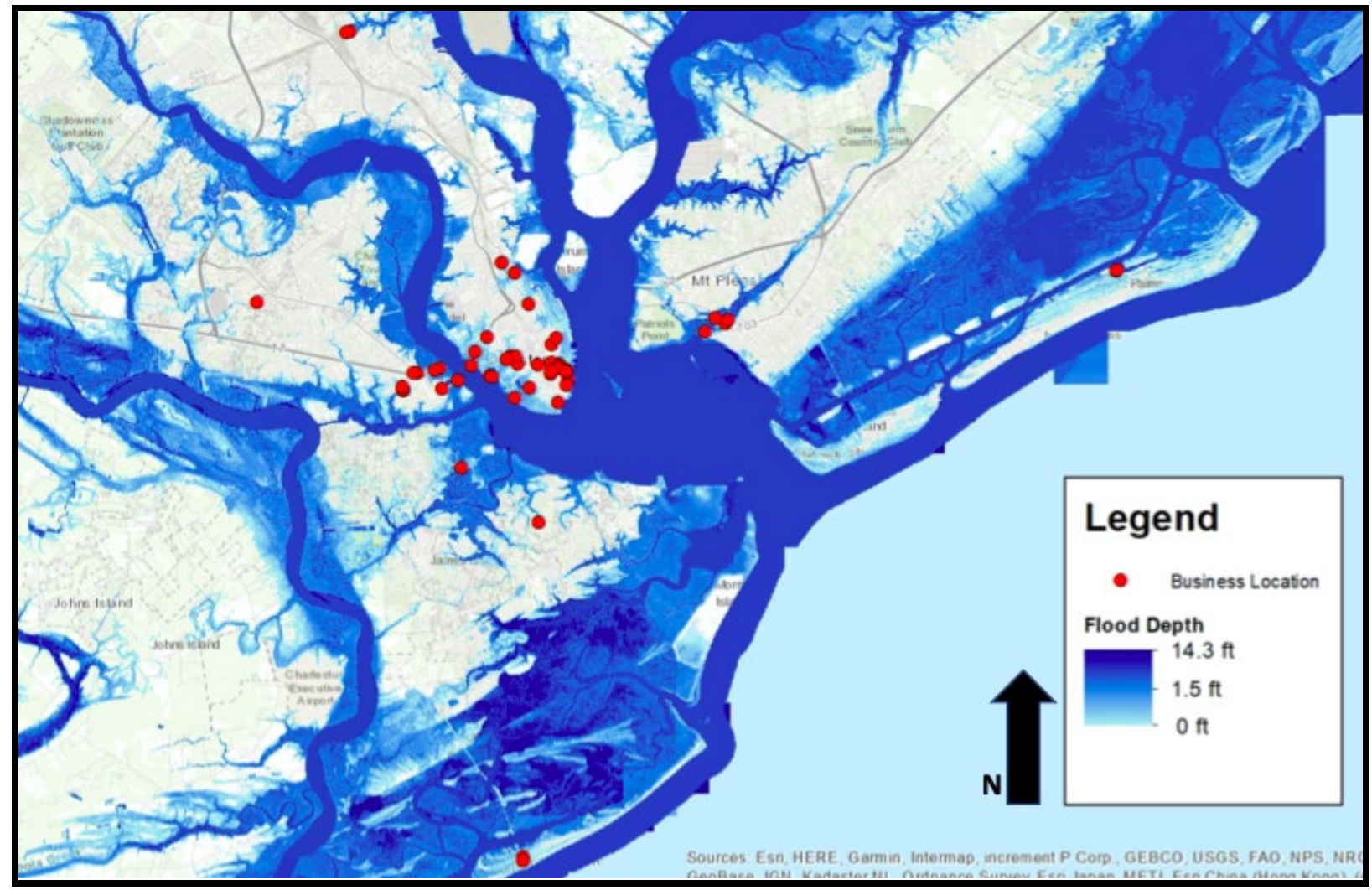

Figure 1. Business locations overlaid on modeled Hurricane Irma flood map (Adapted from Levine and Agudelo, 2019)

\section{Survey Instrument}

The NIST-NOAA Business Recovery instrument is generalizable to additional extreme weather event (EWE) types. As such, the number of questions provided was extensive with the 
aim of learning about: 1 . the best way information may be elicited and 2 . how to provide options for questions that may best address one extreme weather event type over another.

The survey version presented here relates to hurricane-affected SMEs with consideration for their experience with persistent flooding. This survey instrument builds off the NIST Center of Excellence (COE) SME survey work in Lumberton, North Carolina post-Hurricanes Matthew and Florence, which includes a longitudinal business survey component (Watson et al., 2020).

Figure 2 presents a conceptual model that summarizes the factors influencing business interruption and the SME recovery trajectory that we use to guide the survey instrument development.
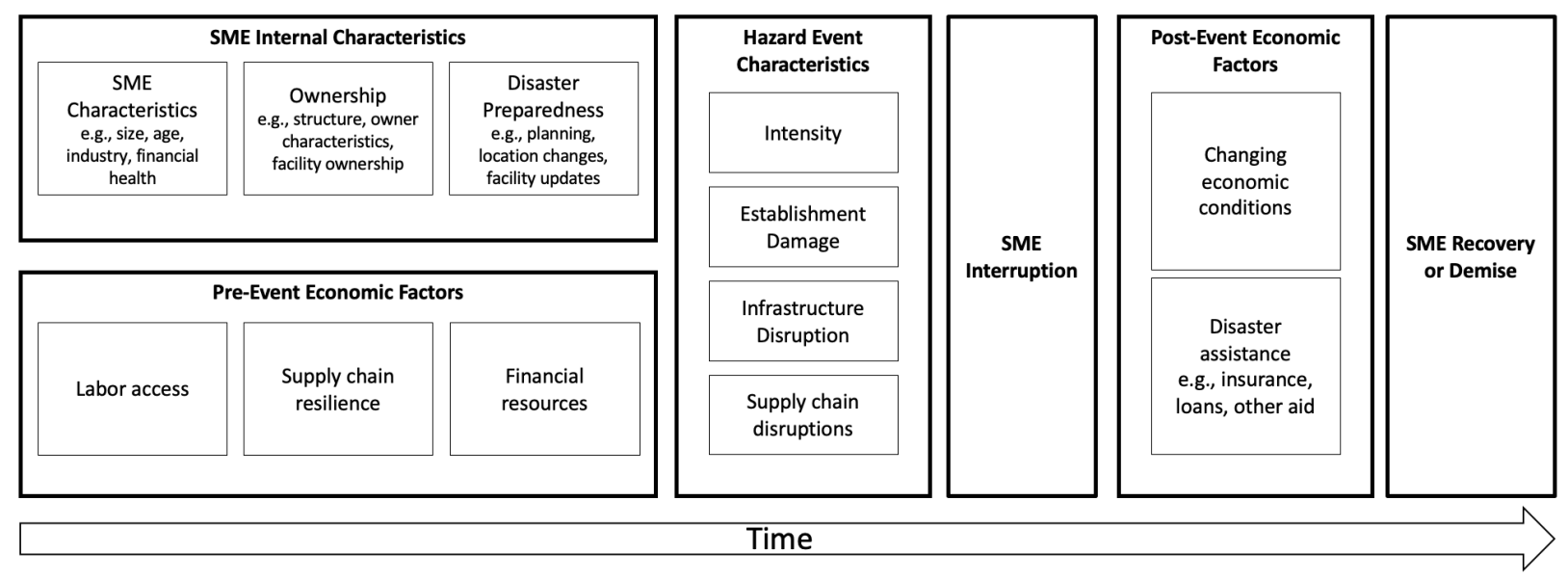

Figure 2. Business Interruption and Recovery schematic

\subsection{Survey Consent}

The following consent script was provided to the participants after a brief, informal introduction. Print copies of the consent were made available to participants and verbal consent was taken.

\section{Post-Hurricane Irma Field Study in Charleston, South Carolina Business Recovery Survey$$
\text { Consent Script }
$$$$
\text { OMB CONTROL NO. 0693-0078 Expiration date: 07/31/2022 }
$$

Hello, my name is (interviewer name) and I am a researcher from (name of university or National Institute of Standards and Technology) in the (department name/Engineering Laboratory). We are conducting a research study on recovery following the flooding that occurred in Charleston, SC in the days following Hurricane Irma. Hurricane Irma hit Florida first and then came up the coast to the Charleston area as a tropical storm on September 11, 2017. We would like to speak with you about how this event affected your business. In particular, we are interested in learning about the 
process of recovering from the flooding. There have been a few different flood events since Hurricane Irma, but we ask that you answer the survey with regards to your experience with Hurricane Irma. There are some sections that ask about flood events more generally as well.

This study is part of a larger project led by the National Oceanic and Atmospheric Administration (NOAA) and the National Institute of Standards and Technology (NIST). Locally, the Carolinas Integrated Sciences and Assessments (CISA) Center and the University of South Carolina are leading this effort. CISA is one of the 11 NOAA funded Regional Integrated Sciences and Assessments (RISA) teams.

We would like to ask you some brief survey questions about your business' experience after the flood as well as some details about your business during this time. Participation will take approximately 15 to 20 minutes, depending on the experience of your business with Hurricane Irma. Your participation is voluntary. If you decide to participate in the study, you may withdraw your consent and stop participation at any time without penalty.

We will be collecting information about the damage to your business, the repair process, and how the flood disrupted your business' employees, supply chain, and revenues. When we report and share our findings, we will combine the data from all participants into summary statistics and tables so no unique individual or business can be identified. There are NO KNOWN RISKS or direct benefits to you. We hope to gain more knowledge on how you and others were affected by Hurricane Irma and the flooding, so that we can learn from your experiences to help Charleston and other communities better prepare for similar events in the future.

So again, we would like to speak with an owner or manager of the business that was here at the time of Hurricane Irma and the flooding OR someone who knows about what happened to the business around that time. Would that person be you? Are you willing to participate?

\subsection{Survey Sections}

The survey instrument consists of seven major component sections: 1. Business background, 2. Damage and business interruption, 3. Employee-related questions, 4. Business information, 5. Business recovery, 6. Recovery finance and mitigation, and 7. Owner / Manager Demographics.

It should be noted that the survey is written in a general manner that does not specify the specific event, i.e., Hurricane Irma, to demonstrate its use across different hurricane and flooding events.

Each survey section is provided below with a short summary. The full survey is provided in Appendix A. 


\subsubsection{Business Background}

This first section of the survey assesses basic business information. In particular the role of the potential respondent is assessed, as is basic information about their experience with ownership or management of the business for which they are responding to the survey.

1. What is the operational status of this business?

1. Open

2. Permanently closed

3. Moved to alternative location (provide address: Not sure/don't know (take notes on any information that can help us identify the status of the business:

2. What event did this location experience? [Hazard Type] [associated "name"]

3. [Take photo of outside of business with geocoding]

(THE FOLLOWING QUESTIONS SHOULD BE ANSWERED BY BUSINESS OWNER OR MANAGER. THE QUESTIONS IN THIS SERVEY RELATE ONLY TO THIS PARTICULAR LOCATION FOR THIS BUSINESS.)

4. What is your role with this business? 1. Owner 2. Manager 3. Owner and Manager

5. How many years have you worked as a business owner/manager?

5.1. At this location: (years)

5.2. In your total career: (years)

\subsubsection{Damage and Business Interruption}

This section of the survey assesses the extent of damage from the hazard event and the extent to which the SME prepared ahead of time. The types of physical damage incurred is based on values from a damage state table (Xiao et al., 2020). Additionally, the level of utility disruption incurred and issues surrounding the delivery of supplies and the capacity of the SME to conduct business from an alternative location.

Information about the potential temporary closure of the SME was included. Of interest is not only if the business temporarily closed, but the reason and who and why the determination was made. Part of this is the type of information reviewed and the source of this information. 
Additionally, the potential influence of the local community (e.g., surrounding businesses and local government agencies) was assessed.

Finally, a qualitative explanation about potential learning from experience with the event was included.

6. Did you undertake any advance preparation/activities to prepare for potential hazards?

1. Yes 2. No

6.1. If Yes [q 6], please describe the specific actions or investments:

7. What kind of physical damage was caused by the event and how severe was the damage? [refer to separate business damage states table]

\begin{tabular}{|c|c|c|c|c|}
\hline Building damage & 1. None 2. Minor & 3. Moderate & 4. Severe & 5. Complete \\
\hline Contents/inventory damage & 1. None 2. Minor & 3. Moderate & 4. Severe & 5. Complete \\
\hline Machinery/equipment damage & 1. None 2. Minor & 3. Moderate & 4. Severe & 5. Complete \\
\hline Important (hard copy) documents? & 1. None 2. Minor & 3. Moderate & 4. Severe & 5. Complete \\
\hline $\begin{array}{l}\text { Record height of water mark if applicable (ask } \\
\text { owner/manager to point to place on the wall } \\
\text { where water reached) }\end{array}$ & inches & & & \\
\hline
\end{tabular}

8. What types of utilities and services were disrupted at this building? And for how long?

(*N/A: not applicable, if your business does not use this service, please indicate N/A; DK: don't know)

\begin{tabular}{|c|c|c|c|c|c|}
\hline $\begin{array}{l}\text { Did your business lose } \\
\text { electric power? }\end{array}$ & 1. Yes 2. No & 3. DK & 4. & $\begin{array}{l}\text { If YES, for how long? } \\
\text { Hours or } \quad \text { days }\end{array}$ & still don't have electricity \\
\hline $\begin{array}{l}\text { [If yes] Did this } \\
\text { business use a } \\
\text { backup generator? }\end{array}$ & 1. Yes 2. No & 3. DK 4 & 4. & Hours or & still using generator \\
\hline $\begin{array}{l}\text { Did your business lose } \\
\text { water? }\end{array}$ & 1. Yes 2. No & 3. DK & 4. & _Hours or __ days & still don't have water \\
\hline $\begin{array}{l}\text { [If yes] Did this } \\
\text { business have a } \\
\text { backup water supply? }\end{array}$ & $\begin{array}{l}\text { 1. Yes 2. No } \\
\text { y? }\end{array}$ & 3. DK 4 & 4. & $\ldots$ Hours or & still using backup supply \\
\hline $\begin{array}{l}\text { Did your business lose } \\
\text { natural gas? }\end{array}$ & 1. Yes 2. No & 3. DK & 4. & Hours or & still don't have natural gas \\
\hline $\begin{array}{l}\text { Did your business lose } \\
\text { sewer? }\end{array}$ & 1. Yes 2. No & 3. DK & 4. & Hours or & still don't have sewer \\
\hline $\begin{array}{l}\text { Did your business lose } \\
\text { landline phone? }\end{array}$ & 1. Yes 2. No & 3. DK & 4. & $\ldots$ Hours or $\_$days & still don't have landline \\
\hline $\begin{array}{l}\text { Did your business lose } \\
\text { cell phone service? }\end{array}$ & 1. Yes 2. No & 3. DK & 4. & Hours or & still don't have cell phone \\
\hline $\begin{array}{l}\text { Did your business lose } \\
\text { Internet access? }\end{array}$ & 1. Yes 2. No & 3. DK & 4. & Hours or & still don't have internet/IT \\
\hline Did your business lose & 1. Yes 2. No & 3. DK & 4. & Hours or & still don't have IT \\
\hline
\end{tabular}




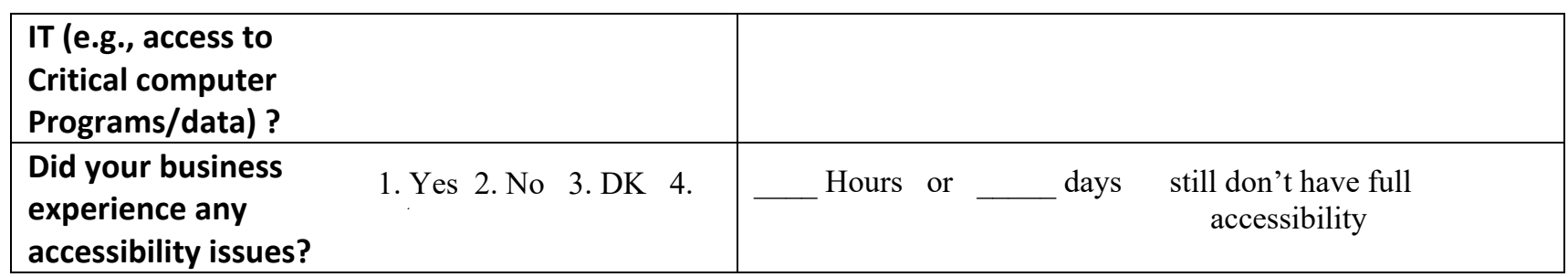

9. How long did it take for your business to resume operations? (all days)

10. How long did it take after the event for employees to access this work location? (all days) 10.1. Was there an alternate work location available for employees to work while the primary location was closed? 1. Yes 2. No

10.2. If [10.1=yes] How far away was the alternate work location from the primary location? (mi.) not applicable

10.3. If [10.1=yes] What type of location was used: 1 . Another physical location owned by the business 2 . Third-party provided location 3. Employee's home

11. Did this business use any other backup systems besides generators or water supply? 1. Yes 2. No

11.1. [If yes] please describe

12. Please add any information about damages from loss of power or other utilities (e.g., leading to inability to move perishable inventory or moisture/mold damage).

13. Was there a stoppage or delay in the delivery of supplies that interrupted business activities (e.g., production or sales)? 1. Yes 2. No 3. N/A If yes, for how long? days) (calendar, not just work

13.1. If yes: Was this a complete or partial stoppage? 1. Complete 2. Partial; Time: (all days, not just work days)

13.2. Did the business experience any other supply chain issues; please explain briefly:

14. Immediately following the event, operations were at:

\begin{tabular}{|c|l|l|l|l|l|}
\hline $\begin{array}{l}100 \% \text { (fully } \\
\text { functioning) }\end{array}$ & $2.80-99 \%$ & $3.50-79 \%$ & $4.30-49 \%$ & $5.1-29 \%$ & $\begin{array}{c}6 . \\
0 \% \text { operations completely } \\
\text { ceased) }\end{array}$ \\
\hline
\end{tabular}

15. Did you make the decision to close the business prior to the event? 1. Yes 2. No 3. Did not close at all

16. If yes [Q15], please answer the following: 
16.1 When did the business make the decision to close (e.g., 1 day, $1 \mathrm{hr}$. before the event hit)?

16.2 What prompted the closure?

17. If no [Q15], please answer the following:

17.1 Did the business close during or after the event?

17.2 When during or after the event did the business close?

17.3. Was it a required closure because it could not function given damage?

18. Who made the final determination? 1. Owner 2. Manager 3. Local policy/requirement 4. Other 19. What information was used to make this decision?

20. Did you use any of the below graphical information to track the event and to decide when to close? $1 . Y$ 2. N

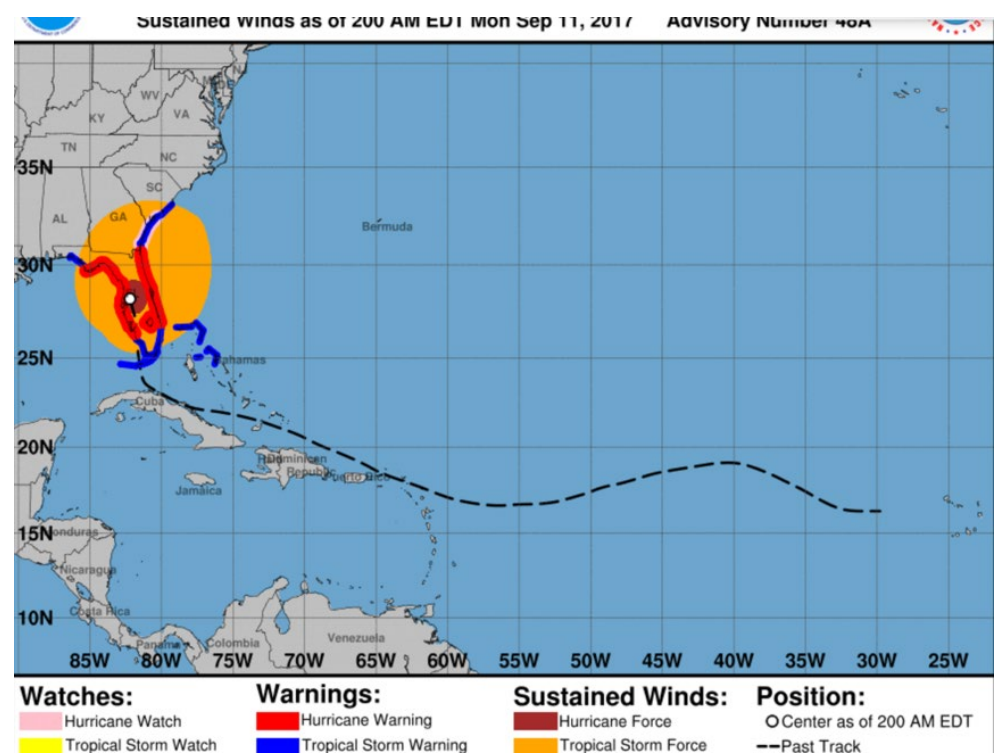

21. Which of the following did you use to get your information? (mark all that apply)

a. local network tv news b. National TV c. Weather Channel d. Accuweather e. Local government, f. Community leaders g. radio $h$. internet source i. friends/family j. social media

k. National Weather Service (directly) I. Phone applications m. Phone push notifications n. OTHER

21.1. What was the most important information used to close your business?

22. How did the business communicate the status of the business (e.g., open or not) to potential customers and the public? (all that apply) 1. Telephone 2. E-mail 3. Text message 4. Social media 5. website 6. Other

23. How dependent is this business on this physical location? (In other words, can this business use virtual location(s) or service(s) during recovery):

1. Not dependent on physical location at all

2. Somewhat dependent on physical location

3. Extremely dependent on physical location 
4. Other

24. How important were the post-disaster decisions of other businesses to remain open or to close in your own decision to remain open or to close?

1. Not at all important

2. Somewhat unimportant

3. Neither important nor unimportant

4. Somewhat important

5. Very important

25. How important were the post-disaster decisions of government agencies to remain open or to close in your own decision to remain open or to close?

1. Not at all important

2. Somewhat unimportant

3. Neither important nor unimportant

4. Somewhat important

5. Very important

26. How might the experience of this event change your approach to planning for a next storm?

\subsubsection{Employee-related Questions}

This section asks respondents to reflect upon the role of the SME's employees in preparing to address the disaster event. Additionally, the questions account for the communication mode between the SME leadership and employees. Employees' ability to report to work during the recovery period is assessed, including the reasons why employees may not have reported. Furthermore, short-term and longer-term health impacts are assessed.

27. Did employees have to spend extra hours at work before the event? 1. Yes 2. No

28. Did employees have to spend extra hours at work during the event? 1. Yes 2. No

29. Did employees have to spend extra hours at work after the event? 1. Yes 2. No

30. How did the business communicate the status of the business and their work schedule to employees?

1. Telephone 2. E-mail 3. Text message 4. Social media 5. Other

31. Did your business experience any issues with employees' ability to report to work (once you began operation post-event)?

31.1. Employee(s) could not report to work due to transportation problems?

1. Yes 2. No

31.2. Employee(s) could not report to work due to the need to fix house?

1. Yes 2. No

31.3. Employee(s) could not report to work because their children not yet back to school? 1. Yes 2. No

31.4. Employee(s) could not report to work due to disaster-related physical health issue? 1. Yes 2. No

31.5. Employee(s) could not report to work due to disaster-related mental health issues? 1. Yes 2. No 
32. Are you aware of any employee long-term health effects arising from the event (e.g., cardiovascular disease, mobility issues)? 1 . Yes 2. No

\subsubsection{Business Information}

The business information section collected information on the characteristics of the business, including: size, sector, and age of the business. The number of full- and part-time employees is asked in this section, both pre- and post-event. The ownership structure of the SME is asked as well as ownership of the business location.

33. In which year was this business established at this location? (Year)

34. What is your primary line of business?
1. Construction
2. Manufacturing
3. Retail trade
4. Service
5. Other (please specify):

35. Before the hazard event, how many full time and part time employees did this business have? And now?
Before:
Full time
Part time

Now: $\quad$ Full time __ Part time

36. Does this business own or rent the building?

1. Own (including buying the building with mortgage) 2. Rent 3. Other

37. What was the business ownership structure before the disaster?

1. Single owner

2. Partnership (multiple owners)

3. Corporation or franchise

4. Cooperative

5. Other (please specify):

\subsubsection{Business Recovery}

The business recovery section poses various questions to gauge how the business is doing during recovery opposed to pre-event. The recovery measures include asking about profitability, capacity, customer loss, as well as changes in customer and souring location (i.e., inside the community). The section also asks about oral or written resilience plans and the potential for plan development post-event. 
38. Where do you feel your business stands in the process of recovery today?

- Still in operation but will never recover (please explain)

- Still in survival/response mode

- Recovering

- Mostly recovered

- Fully recovered

39. Compared to before the event, what is the \% capacity at which the business is operating today? $\%$

(For "capacity," consider aspects of the business that are most important to you, like the quality and/or quantity of service or product offerings. For example: $50 \%$ for reduced capacity, $110 \%$ for increased capacity, or $0 \%$ for businesses that have not resumed operations.)

40. How has the business revenue changed since Hurricane Irma? (Please reference gross revenue.)

1. Decreased greatly

2. Decreased

3. Stay the same

4. Increased

5. Increased greatly

41. How has profitability of the business been impacted by Hurricane Irma? How profitable was your business before Hurricane Irma? What about now?

\begin{tabular}{|l|lccccc|}
\hline 41.1. Before & 0. & Highly Profitable & 1. Profitable & 2. Breaking even & 3. Unprofitable & 4. Closed \\
\hline 41.2. Now & 0. & Highly Profitable & 1. Profitable & 2. Breaking even & 3. Unprofitable & 4. Closed \\
\hline
\end{tabular}

42. Did this business experience a loss of customers? Please think about this question in the context of immediately pre-event to when operations (above $0 \%$ ) began again at the location
1. Lost customers $\%$ loss)
2. Remained the same 3. Gained customers $\%$ gain)

43. Please indicate your level of agreement with the following statements.

\begin{tabular}{|l|l|l|l|}
\hline $\begin{array}{l}43.1 . \\
\text { More of our customers come from outside our } \\
\text { city than they did before the disaster }\end{array}$ & 1. Agree & 2. No change & 3. Disagree \\
\hline $\begin{array}{l}\text { 43.2. } \\
\begin{array}{l}\text { We now source from more suppliers outside } \\
\text { our city than we did before the disaster }\end{array}\end{array}$ & 1. Agree & 2. No change & 3. Disagree \\
\hline
\end{tabular}

44. Did your business have any type of oral or written plan covering business continuity plan, disaster plan, employee training, (circle all that apply) to guide the actions of you and your employees through the hazard? $\quad$ 1. Yes $\quad 2$. No 3. other 44.1 [If 42="Yes"] Oral or written plan?

44.2. [If $42=" Y$ "Y"] Do you feel the plan enabled you to recover your operations more quickly than if you had no plan? $\begin{array}{llll}\text { 1. Yes } & \text { 2. No } & 3 . \mathrm{D} / \mathrm{K}\end{array}$

44.3. [If 44="Yes"] Have you updated your plan with the lessons learned from this event? 1. Yes 2. No 3. $D / K$ 
44.4. [If 44="No"] If you had no plan prior to this event, are you developing a plan now (or in the near future) based on the lessons learned from this event? 1. Yes 2. No 3. Maybe

\subsubsection{Recovery Finance and Mitigation}

The recovery finance and mitigation section asks about financial recovery and planning, including insurance coverage and mitigation actions following the event. In particular, questions related to insurance and other financial assistance asks about whether they applied for and/or obtained funds and the associated timing.

In particular, the respondent's perception of the persistence and severity of hurricane events versus persistent flooding was asked. Additionally, experience with the extent to which these event types had been experiences by the SME was asked. Finally, local government resources obtained and perceived as needed was addressed in this section.

45. Did you have insurance coverage related to this disaster type on the building, contents, or business $\begin{array}{llll}\text { interruption before the event? } 1 \text {. Yes } & \text { 2. No } & \text { 3. D/K }\end{array}$

45.1. [If yes to 45] What types of insurance coverage do you have (i.e. building, contents, business interruption, liability, etc.)?

$4 5 . 2 \longdiv { \text { [If no to 45] Is there a reason that you do not have related insurance coverage? } }$

46. What was the approximate cost of your business damages from Hurricane Irma?

47. How did you finance your business' recovery from the event? [Please indicate with a dollar amount]

\begin{tabular}{|l|l|}
\hline Personal savings & \\
\hline Credit card & \\
\hline Corporate assistance (or assistance from another branch/location) & \\
\hline Insurance & \\
\hline Donations & \\
\hline Private bank loans & \\
\hline Crowd funding & \\
\hline Assistance from friends or family programs (e.g. Small Business Administration loans) & \\
\hline $\begin{array}{l}\text { Federal assistance program) } \\
\text { (List: }\end{array}$ & \\
\hline $\begin{array}{l}\text { State assistance programs (e.g. Resilient Recovery Loan Program) } \\
\text { (List: }\end{array}$ & \\
\hline $\begin{array}{l}\text { Local assistance programs (e.g. grant or loan from the city or local non-profit) } \\
\text { (List: }\end{array}$ & \\
\hline Other: & \\
\hline
\end{tabular}




\begin{tabular}{|l|l|} 
Other: & \\
\hline Other: & \\
\hline TOTAL & \\
\hline
\end{tabular}

** Bridge Loan: typically, loans between $\$ 1,000$ and $\$ 50,000$ for up to one year. While the bridge loan is a source of expedient funds, it is not designed to be the primary source of assistance for affected small businesses

48. [If $47=$ "yes, to insurance"] Did you file claims and receive money?

\begin{tabular}{|l|l|l|l|l|l|l|}
\hline & $\begin{array}{l}\text { Required to } \\
\text { have } \\
\text { insurance? }\end{array}$ & $\begin{array}{l}\text { Had } \\
\text { Insurance? }\end{array}$ & Filed Claim? & $\begin{array}{l}\text { Received } \\
\text { Money? }\end{array}$ & $\begin{array}{l}\text { Received } \\
\text { When? } \\
\text { (months } \\
\text { after } \\
\text { event) }\end{array}$ & $\begin{array}{l}\text { \% } \\
\text { insurance } \\
\text { covered }\end{array}$ \\
\hline Building & $\begin{array}{l}\text { 1. Yes } \\
\text { 2. No } \\
\text { 3. D/K }\end{array}$ & $\begin{array}{l}\text { 1. Yes } \\
\text { 2. No } \\
\text { 3. D/K }\end{array}$ & $\begin{array}{l}\text { 1. Yes 2. No 3. } \\
\text { We paid for all }\end{array}$ & $\begin{array}{l}\text { 1. Yes } \\
\text { 2. No } \\
\text { 3. pending }\end{array}$ & & \\
\hline $\begin{array}{l}\text { Content } \\
\text { business } \\
\text { insurance/most } \\
\text { relevant to } \\
\text { renters) }\end{array}$ & $\begin{array}{l}\text { 1. Yes } \\
\text { 2. No } \\
\text { 3. D/K }\end{array}$ & $\begin{array}{l}\text { 1. Yes } \\
\text { 2. No } \\
\text { 3. D/K }\end{array}$ & $\begin{array}{l}\text { 1. Yes 2. No 3. } \\
\text { We paid for all }\end{array}$ & $\begin{array}{l}\text { 1. Yes } \\
\text { 2. No } \\
\text { 3. pending }\end{array}$ & & \\
\hline $\begin{array}{l}\text { Business } \\
\text { interruption }\end{array}$ & $\begin{array}{l}\text { 1. Yes } \\
\text { 2. No } \\
\text { 3. D/K }\end{array}$ & $\begin{array}{l}\text { 1. Yes } \\
\text { 2. No } \\
\text { 3. D/K }\end{array}$ & $\begin{array}{l}\text { 1. Yes 2. No 3. } \\
\text { We paid for all }\end{array}$ & $\begin{array}{l}\text { 1. Yes } \\
\text { 2. No } \\
\text { 3.pending }\end{array}$ & & \\
\end{tabular}

49. What assistance did you need and not get? (monetary or in-kind):

50. How long do you estimate this business could function in a deficit (X days, weeks, months)?

51. What mitigation actions have you taken since Hurricane Irma? (select all that apply)

[NOTE: Please refer to Descriptions of Business Mitigation Activities document for further description]

\begin{tabular}{|c|c|c|c|c|c|c|}
\hline & $\begin{array}{l}\text { Business } \\
\text { Elevation }\end{array}$ & & Landscaping & & Dry-proofing & $\begin{array}{ll}\text { d. Flood- } \\
\text { proofing }\end{array}$ \\
\hline e. & $\begin{array}{l}\text { Have an } \\
\text { emergency plan } \\
\text { in-place }\end{array}$ & & $\begin{array}{l}\text { Purchase } \\
\text { increased } \\
\text { insurance }\end{array}$ & & $\begin{array}{l}\text { Maintain } \\
\text { offsite backups }\end{array}$ & \\
\hline
\end{tabular}

52. Have there been changes in the severity and frequency of hurricanes affecting your business?

\begin{tabular}{|c|c|c|c|}
\hline $\begin{array}{l}52.1 . \\
\text { Severity (damage) }\end{array}$ & 1. Decreasing greatly 2 . Decreasing & 3. Unchanged & 4. Increasing 5. Increasing greatly \\
\hline $\begin{array}{l}52.2 . \\
\text { Frequency }\end{array}$ & 1. Decreasing greatly 2 . Decreasing & 3. Unchanged & 4. Increasing 5. Increasing greatly \\
\hline
\end{tabular}

53. How many similar hurricanes have occurred at this location that have required your business to close temporarily (e.g., the business was inaccessible, decided to close)? names/dates) (if applicable, list 
54. Have there been changes in the severity and frequency of recurrent floods affecting your business?

\begin{tabular}{|c|c|c|c|}
\hline $\begin{array}{l}54.1 . \\
\text { Severity (damage) }\end{array}$ & 1. Decreasing greatly 2 . Decreasing & 3. Unchanged & 4. Increasing 5 . Increasing greatly \\
\hline $\begin{array}{l}54.2 . \\
\text { Frequency }\end{array}$ & 1. Decreasing greatly 2 . Decreasing & 3. Unchanged & 4. Increasing 5. Increasing greatly \\
\hline
\end{tabular}

54.3 How many recurrent floods has your business experienced in the last year?

54.4 How have they impacted your business (i.e. parking lot was flooded, water entered the building, could not drive to work)

55. Are there resources you've gotten from your local government that have been useful? Are there things you'd like to see provided by local government?

\subsubsection{Owner / Manager Demographics}

This section addresses respondent demographics. Age and educational attainment as well as race and household income are asked to act as control variables in future analysis.

56. What is your age? (years)

57. What is your number of years of schooling? Enter number of years and indicate type of diploma or degree:

1. Some high school, but didn't finish

2. Completed High School

3. Some college, but didn't finish

4. Associate degree

5. Bachelors

6. Masters or higher degree

58. Are you Hispanic? 1. Yes 2. No

59. What is your race? Select one or more (check all relevant)

\begin{tabular}{|l|l|}
\hline$\circ$ White & $\circ \quad$ Asian \\
$\circ$ Black or African American & $\circ \quad$ Native Hawaiian or other Pacific Islander \\
$\circ$ American Indian or Native American & \\
\hline
\end{tabular}

60. What is your household income? (per year before taxes)

\begin{tabular}{|l|l|}
\hline a. Under $\$ 25,000$ & e. $\$ 80,000-\$ 99,999$ \\
\hline b. $\$ 25,000-\$ 39,999$ & f. $\$ 100,000-\$ 124,999$ \\
\hline c. $\$ 40,000-\$ 59,999$ & g. $\$ 125,000-\$ 149,999$ \\
\hline d. $\$ 60,000-\$ 79,999$ & h. Over $\$ 150,000$ \\
\hline
\end{tabular}




\subsection{Survey Approvals}

The final business survey instrument also went through the review for the Paperwork Reduction Act (PRA) (1995. Pub. L. No. 104-13, 109 Stat 163). The purpose of this review is to: "ensure the greatest possible public benefit from and maximize the utility of information created, collected, maintained, used, shared, and disseminated by or for the Federal Government; and to "improve the quality and use of Federal information to strengthen decision making, accountability, and openness in Government and society.” The PRA approval package is available upon request.

The instrument and data collection methodology were also approved by the Institutional Review Board (IRB) at both NIST and the University of South Carolina, which oversees human subjects research. The IRB conducts reviews of protocols that involve research with human subjects to ensure protection for human research participants through advance and periodic independent review of the ethical acceptability of proposals for human research. The IRB protocols for this survey are available upon request. 


\section{Data Collection Methodology}

\subsection{Training}

A team of Master-level students were hired to complete the in-person surveying and data entry. These teams were then overseen by a doctoral candidate on the core research team. Training of the teams included both in-person and virtual training activities. The students completed Collaborative Institutional Training Initiative (CITI) human subject training before being introduced to the survey instrument.

To become familiar with the instrument, the team practiced delivering the informed consent introduction and then asking the survey questions. This exercise was completed in-person with the faculty advisor and doctoral candidate who had pilot tested the instrument previously.

To ensure consistent delivery of the survey, the doctoral candidate then accompanied the master's students in the field. The doctoral candidate observed and provided comments to each student after they completed the surveys. The students then split into teams of two to go in-person to complete their full list of surveys for the day. They walked into each business, introduced themselves and the survey, and then asked to speak with the owner or manager. One student asked the survey questions while the other student acted as the notetaker on the paper survey. At the end of the surveying session, the students would provide the respondent with a postcard with further information about the project and contact information for the research team.

\subsection{Data Entry}

After each day of surveying, the student pairs would then go over the survey answers and ensure all information was clearly written and understandable to the notetaker. The notetaker was then responsible for inputting the collected data into a digital survey database for future analysis. The survey database was created in Excel and included all question responses in their raw form (e.g., text responses remained as text) as well information on the date the survey was conducted, who conducted the survey, and in many cases links to a separate archive of photographs of the business.

The pairs would also complete a post-surveying day report that included the businesses contacted, result of the contacts (e.g., completed survey, return later, soft refusal, hard refusal, no 
longer at that location), contact at the business if available, and number of hours spent surveying. All contact with businesses was tracked in the Business Communication Form (Appendix E).

\subsection{Follow-up work}

The pilot surveying was completed during the summer of 2019, which is the tourism season in Charleston, South Carolina. This resulted in tourism-based businesses being frequently unavailable for walk-in surveying. A system to address follow-up surveying was developed that involved three components, calling ahead, setting survey appointments, and leaving surveys behind.

The student team would call any businesses that were not available for walk-in surveying based on the post-surveying day reports. During the call, they would confirm if the business was eligible to complete the survey and, if eligible, would set up an appointment to complete the survey.

If neither the walk-in nor call ahead in-person survey techniques yielded a response, the students would then drop off a survey to be completed by the owner or manager. The survey also included a business card with the students' contact information and a postcard with information about the survey (Figure 3). These surveys were then picked up by the team seven days later. During the pick-up process, the student team would review any empty responses with the business owner or manager and check to see if they had any questions. If they returned twice for the survey without a successful completion, the student team then labelled the business as a "hard refusal" in their surveying report and attempted to survey the business at the address directly to the left of the incomplete business record. 


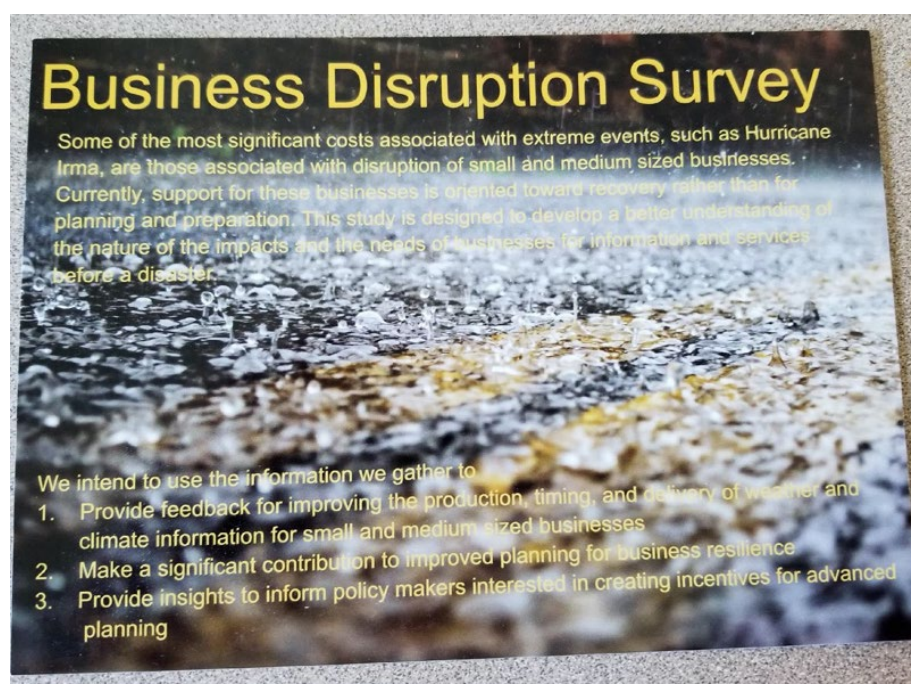

Figure 3. Leave-behind postcard with information about the survey

\section{Lessons Learned}

The field experience yielded a number of lessons specific to data collection. In sharing these lessons, some additional context on Charleston is needed. Some of these lessons learned may only translate to best practices in communities with features and experiences similar to Charleston. Here we provide a short list of lessons learned.

- Prior hazard experience and/or familiarity may help with interest and survey participation.

Members of the greater Charleston, SC business community are generally well aware of flooding-related events with many having experienced frequent high tide flooding events as well as a major storm flooding event and hurricane driven flooding in the two years preceding Hurricane Irma. The flooding topic received considerable news coverage in the region over a number of years. Perhaps as a consequence of those experiences, the researchers found that many SME owners/managers approached were friendly and interested in the research effort even if they opted to not participate in the survey.

- Certain types of communities and perhaps certain types of businesses (e.g., hospitality and retail) may be more likely to engage with surveyors. 
Charleston, especially the downtown area, is a tourist destination and as such, many SMEs are in the hospitality and retail sectors. In such sectors there tends to be a willingness to engage with those who are "stopping in." It is unclear whether this openness is a cultural norm in the pilot location or typical of this SME sector.

- Learn the busy periods for the business sectors that you are targeting; they are likely different by sector/area of town.

A number of SMEs have set delivery days and busy periods (e.g., customer surges on the premise). For example, many restaurants are least busy during the period after lunch until the start of their dinner service. In many cases, it makes sense to go to the business in-person with the expectation of making a time for a follow-up meeting to administer the survey. One community hosted many weekly vacation rentals that turned over on Sundays meaning that Mondays were especially busy days for retailers as new guests shopped for the week.

- Working with a local university that is recognizable to community members boosts response rates.

There is an element of familiarity and in-group affect that seems to encourage the SMEs respond more readily. But additionally, local researchers have a stake in the effort that extends outside of research. The community is part of their community as private individuals, not just researchers.

\section{Future Work}

The ability to withstand hazard-related risks is important to the short- and long-term viability of SMEs, and therefore, to local economies and overall resilience. This research protocol, and the larger project with which it is associated, are focused on how resilience research can be most beneficial to smaller (even micro-scale) businesses; and most informative to policies that can inspire improved planning for extremes. As climate change continues to create economic and regional shifts, sectoral interactions and stressors will impact recovery and resilience (Clarke et al., 2018). 
This work demonstrates that there are issues of importance at the local, regional and national levels. Survey work like this stands to highlight the commonalities across levels where disaster research can inform national level issues of resilience planning and enable effective recovery. But it also provides the ability to narrow in on where there are distinct differences between localities and regions. For example, the tourism businesses along the coastline might share certain types of impacts that those inland may not experience, regardless of city limits and jurisdictions. Furthermore, those businesses within city limits, regardless of sector might share a set of resilience related resources not available to those in the next town over. Future work on the intersections between business and climate resilience would benefit from maintaining these scales of difference in order to better understand how information and resources can be best allocated.

Literature has discussed the need to address compound and cascading natural and technological hazards with effects or causes originating from an initial hazard (Clarke et al. 2018; Cutter, 2018). In the past, business disruption survey efforts have largely focused upon discrete events. In this survey we begin to approach a view of complex events, i.e., hurricane impacts and high tide flooding. In a general sense, multi-hazard or compound risk research is gaining additional traction with the onset of COVID-19 (Hillier et al., 2020; "Moving beyond Isolated Events," 2020; Phillips et al., 2020; Raymond et al., 2020). Yet, complex event research overwhelming focuses on physical interactions and neglects many social drivers (Zscheischler et al., 2020).

The survey presented herein has laid the groundwork for continued efforts that address potential and realized complex disaster events in the context of the COVID-19 pandemic. Two such efforts have grown out of the development and execution of the "NIST/NOAA SME Recovery Assessment" in the greater Charleston, SC area. Helgeson et al. (2020) present an online survey focused on the experiences of SMEs in addressing complex event resilience, specifically applied to natural hazards and the COVID-19 pandemic. Furthermore, efforts in the pilot region and the Carolinas more broadly are underway (E. D. Pierel, SPARC Project 80003619). Learning is fundamental to problem-solving generally and is critical to advancing SMEs' coping capacity. As surveys like the one presented herein are considered in the context of COVID-19, it is critical to understand how SMEs can apply learned fundamentals of preparation and risk reduction to unanticipated circumstances, such as how best to reduce impacts of natural hazards and extreme weather events in the COVID-19 context. 


\section{Appendix A - Complete Survey (Note Version) \\ Business Recovery Survey - NIST/NOAA SME Recovery Assessment}

SUBJECT TO: OMB CONTROL \#0693-0078; EXPIRATION DATE: 07/31/2022 (NIST GENERIC CLEARANCE FOR COMMUNITY RESILIENCE DATA COLLECTIONS)

Date:

Surveyor(s):

PIN:

Business Name:

Address:

Result Completion Code:

\begin{tabular}{|c|c|c|c|c|}
\hline & Completed survey & 4. hard refusal & 7. incomplete/partial & $\begin{array}{l}\text { 10. no answer or } \\
\text { response, but } \\
\text { evidence/confirmation } \\
\text { operating }\end{array}$ \\
\hline 2. & $\begin{array}{l}\text { Ineligible, no } \\
\text { manager/owner to } \\
\text { answer }\end{array}$ & $\begin{array}{l}\text { 5. Soft refusal, set } \\
\text { time for future } \\
\text { interview }\end{array}$ & $\begin{array}{l}\text { 8. non-operational } \\
\text { business - closed } \\
\text { BEFORE event }\end{array}$ & $\begin{array}{l}\text { 11. no access (e.g., fence } \\
\text { preventing entry) }\end{array}$ \\
\hline 3. & $\begin{array}{l}\text { Wrong address, } \\
\text { could not locate }\end{array}$ & $\begin{array}{l}\text { 6. Soft refusal, left } \\
\text { form }\end{array}$ & $\begin{array}{l}\text { 9. non-operational - } \\
\text { closed AFTER event / } \\
\text { destroyed }\end{array}$ & $\begin{array}{l}\text { 12. ineligible, business } \\
\text { (name) different than } \\
\text { the one expected }\end{array}$ \\
\hline
\end{tabular}

Federal classification of the business:

A. Woman-owned B. Minority certified by the SBA (8a) C. Veteran-owned D. NONE

Business Background

1. What is the operational status of this business?

O Open

- Permanently closed

- Moved to alternative location (provide address:

Not sure/don't know (take notes on any information that can help us identify the status of the business:

2. What event did this location experience? [Hazard Type] [associated "name"]

3. [Take photo of outside of business with geocoding]

(THE FOLLOWING QUESTIONS SHOULD BE ANSWERED BY BUSINESS OWNER OR MANAGER. THE QUESTIONS IN THIS SERVEY RELATE ONLY TO THIS PARTICULAR LOCATION FOR THIS BUSINESS.)

4. What is your role with this business? 1. Owner 2. Manager 3. Owner and Manager

5. How many years have you worked as a business owner/manager?

5.3. At this location: (years) 


\section{Damage and Business Interruption}

6. Did you undertake any advance preparation/activities to prepare for potential hazards?

2. Yes 2. No

6.1. If Yes [q 6], please describe the specific actions or investments:

7. What kind of physical damage was caused by the event and how severe was the damage? [refer to separate business damage states table]

\begin{tabular}{|c|c|c|c|c|}
\hline Building damage & 1. None 2. Minor & 3. Moderate & 4. Severe & 5. Complete \\
\hline Contents/inventory damage & 1. None 2. Minor & 3. Moderate & 4. Severe & 5. Complete \\
\hline Machinery/equipment damage & 1. None 2. Minor & 3. Moderate & 4. Severe & 5. Complete \\
\hline Important (hard copy) documents? & 1. None 2. Minor & 3. Moderate & 4. Severe & 5. Complete \\
\hline $\begin{array}{l}\text { Record height of water mark if applicable (ask } \\
\text { owner/manager to point to place on the wall } \\
\text { where water reached) }\end{array}$ & inches & & & \\
\hline
\end{tabular}

8. What types of utilities and services were disrupted at this building? And for how long?

(* N/A: not applicable, if your business does not use this service, please indicate N/A; DK: don't know)

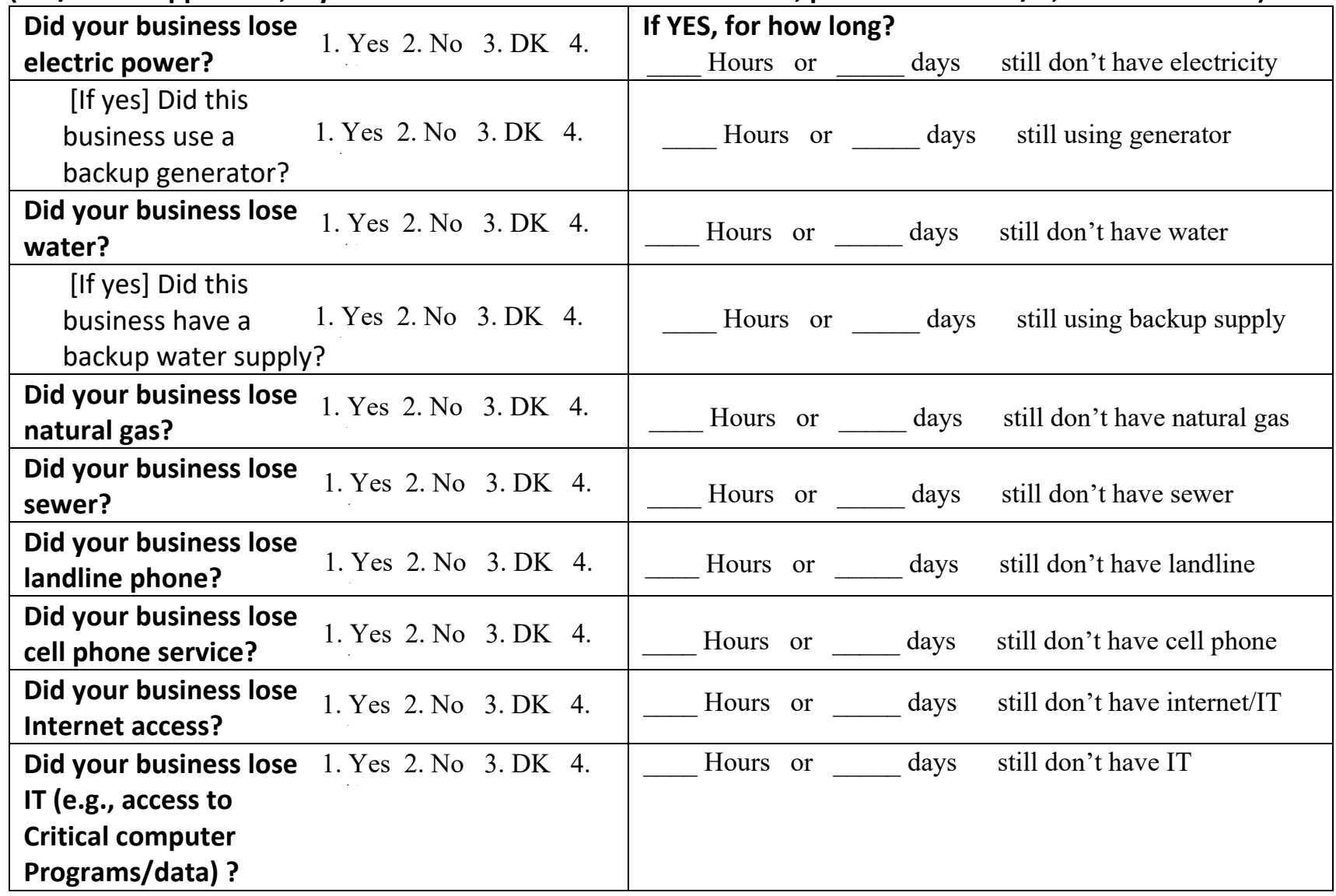




\begin{tabular}{|ll|lll|}
\hline $\begin{array}{l}\text { Did your business } \\
\text { experience any } \\
\text { accessibility issues? }\end{array}$ & 1. Yes & 2. No 3. DK 4. & Hours or __days $\quad \begin{array}{l}\text { still don't have full } \\
\text { accessibility }\end{array}$ \\
\hline
\end{tabular}

9. How long did it take for your business to resume operations? (all days)

10. How long did it take after the event for employees to access this work location? (all days)

10.4. Was there an alternate work location available for employees to work while the primary location was closed? 1. Yes 2. No

10.5. If [10.1=yes] How far away was the alternate work location from the primary location? (mi.) not applicable

10.6. If [10.1=yes] What type of location was used: 1 . Another physical location owned by the business 2 . Third-party provided location 3 . Employee's home

11. Did this business use any other backup systems besides generators or water supply? 1 . Yes 2. No

11.1. [If yes] please describe

12. Please add any information about damages from loss of power or other utilities (e.g., leading to inability to move perishable inventory or moisture/mold damage).

13. Was there a stoppage or delay in the delivery of supplies that interrupted business activities (e.g., production or sales)? 1. Yes 2. No 3. N/A If yes, for how long? (calendar, not just work days)

13.3. If yes: Was this a complete or partial stoppage? 1. Complete 2. Partial; Time: (all days, not just work days)

13.4. Did the business experience any other supply chain issues; please explain briefly:

14. Immediately following the event, operations were at:

\begin{tabular}{|l|l|l|l|l|l|}
\hline $\begin{array}{l}100 \% \text { (fully } \\
\text { functioning) }\end{array}$ & $80-99 \%$ & $50-79 \%$ & $30-49 \%$ & $1-29 \%$ & $\begin{array}{l}0 \% \text { operations completely } \\
\text { ceased) }\end{array}$ \\
\hline
\end{tabular}

15. Did you make the decision to close the business prior to the event? 1. Yes 2. No 3. Did not close at all

16. If yes [Q15], please answer the following:

16.3 When did the business make the decision to close (e.g., 1 day, $1 \mathrm{hr}$. before the event hit)?

16.4 What prompted the closure?

17. If no [Q15], please answer the following: 
17.1 Did the business close during or after the event?

17.2 When during or after the event did the business close?

17.3. Was it a required closure because it could not function given damage?

18. Who made the final determination? 1. Owner 2. Manager 3. Local policy/requirement 4. Other

19. What information was used to make this decision?

20. Did you use any of the below graphical information to track the event and to decide when to close?

1. Y 2. N

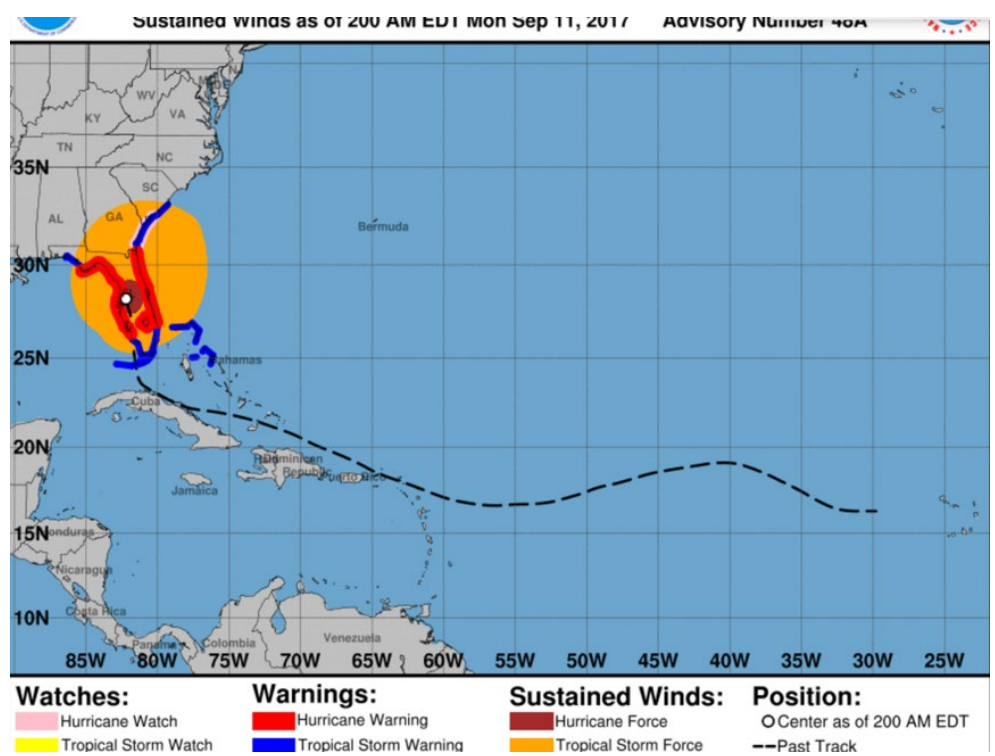

21. Which of the following did you use to get your information? (mark all that apply)

b. local network tv news b. National TV c. Weather Channel d. Accuweather e. Local government,

f. Community leaders g. radio $h$. internet source i. friends/family j. social media

k. National Weather Service (directly) I. Phone applications m. Phone push notifications n. OTHER

21.1. What was the most important information used to close your business?

22. How did the business communicate the status of the business (e.g., open or not) to potential customers and the public? (all that apply) 1. Telephone 2. E-mail 3. Text message 4. Social media 5. website 6. Other

23. How dependent is this business on this physical location? (In other words, can this business use virtual location(s) or service(s) during recovery):

5. Not dependent on physical location at all

6. Somewhat dependent on physical location

7. Extremely dependent on physical location

8. Other

24. How important were the post-disaster decisions of other businesses to remain open or to close in your own decision to remain open or to close?

- Not at all important 
- Somewhat unimportant

- Neither important nor unimportant

- Somewhat important

○ Very important

25. How important were the post-disaster decisions of government agencies to remain open or to close in your own decision to remain open or to close?

- Not at all important

- Somewhat unimportant

- Neither important nor unimportant

- Somewhat important

○ Very important

26. How might the experience of this event change your approach to planning for a next storm?

\section{Employee-related Questions}

27. Did employees have to spend extra hours at work before the event? 1. Yes 2. No

28. Did employees have to spend extra hours at work during the event? 1. Yes 2. No

29. Did employees have to spend extra hours at work after the event? 1. Yes 2. No

30. How did the business communicate the status of the business and their work schedule to employees? 1. Telephone 2. E-mail 3. Text message 4. Social media 5. Other

31. Did your business experience any issues with employees' ability to report to work (once you began operation post-event)?

31.1. Employee(s) could not report to work due to transportation problems? 1.Yes 2. No

31.2. Employee(s) could not report to work due to the need to fix house? 1. Yes 2. No

31.3. Employee(s) could not report to work because their children not yet back to school? 1. Yes 2. No

31.4. Employee(s) could not report to work due to disaster-related physical health issue? 1. Yes 2. No

31.5. Employee(s) could not report to work due to disaster-related mental health issues? 1. Yes 2. No

32. Are you aware of any employee long-term health effects arising from the event (e.g., cardiovascular disease, mobility issues)? 1 . Yes 2 . No

\section{Business Information}

33. In which year was this business established at this location? (Year)

34. What is your primary line of business?
6. Construction
7. Manufacturing
8. Retail trade
9. Service
10. Other (please specify): 
35. Before the hazard event, how many full time and part time employees did this business have? And now?

\begin{tabular}{lll} 
Before: & Full time & Part time \\
Now: & Full time & Part time \\
\hline
\end{tabular}

36. Does this business own or rent the building?

2. Own (including buying the building with mortgage) 2. Rent 3. Other

37. What was the business ownership structure before the disaster?

6. Single owner

7. Partnership (multiple owners)

8. Corporation or franchise

9. Cooperative

10. Other (please specify):

\section{Business Recovery}

38. Where do you feel your business stands in the process of recovery today?

- Still in operation but will never recover (please explain)

- Still in survival/response mode

- Recovering

- Mostly recovered

- Fully recovered

39. Compared to before the event, what is the \% capacity at which the business is operating today? $\%$

(For "capacity," consider aspects of the business that are most important to you, like the quality and/or quantity of service or product offerings. For example: $50 \%$ for reduced capacity, $110 \%$ for increased capacity, or $0 \%$ for businesses that have not resumed operations.)

40. How has the business revenue changed since Hurricane Irma? (Please reference gross revenue.)

1. Decreased greatly

6. Decreased

7. Stay the same

8. Increased

9. Increased greatly

41. How has profitability of the business been impacted by Hurricane Irma? How profitable was your business before Hurricane Irma? What about now?

\begin{tabular}{|l|ll|}
\hline 41.1. Before & $\begin{array}{l}\text { a. Highly Profitable 1. Profitable 2. Breaking even 3. Unprofitable } 4 . \\
\text { Closed }\end{array}$ \\
\hline 41.2. Now & 21. Highly Profitable 1. Profitable 2. Breaking even $\quad$ 3. Unprofitable 4. Closed \\
\hline
\end{tabular}

42. Did this business experience a loss of customers? Please think about this question in the context of immediately pre-event to when operations (above $0 \%$ ) began again at the location 
1. Lost customers (__ _ loss) 2. Remained the same 3. Gained customers (__ \% gain)

43. Please indicate your level of agreement with the following statements.

\begin{tabular}{|l|l|l|l|}
\hline $\begin{array}{l}\text { 43.1. } \\
\text { More of our customers come from outside our } \\
\text { city than they did before the disaster }\end{array}$ & 1. Agree & 2. No change & 3. Disagree \\
\hline $\begin{array}{l}\text { 43.2. } \\
\begin{array}{l}\text { We now source from more suppliers outside } \\
\text { our city than we did before the disaster }\end{array}\end{array}$ & 1. Agree & 2. No change & 3. Disagree \\
\hline
\end{tabular}

44. Did your business have any type of oral or written plan covering business continuity plan, disaster plan, employee training, (circle all that apply) to guide the actions of you and your employees through the hazard? $\quad$ 1. Yes $\quad$ 2. No 3. other

44.1 [If 42="Yes"] Oral or written plan?

44.2. [If 42="Yes"] Do you feel the plan enabled you to recover your operations more quickly than if you had no plan? $\begin{array}{llll}1 \text {. Yes } & 2 \text {. No } & \text { 3. D/K }\end{array}$

44.3. [If $44=" Y e s "]$ Have you updated your plan with the lessons learned from this event? 1. Yes 2. No 3. D/K

44.4. [If $44=" N o "]$ If you had no plan prior to this event, are you developing a plan now (or in the near future) based on the lessons learned from this event? 1. Yes 2. No 3. Maybe

\section{Recovery Finance and Mitigation}

45. Did you have insurance coverage related to this disaster type on the building, contents, or business $\begin{array}{llll}\text { interruption before the event? } 1 \text {. Yes } & \text { 2. No } & \text { 3. D/K }\end{array}$

45.1. [If yes to 45] What types of insurance coverage do you have (i.e. building, contents, business interruption, liability, etc.)?

45.2. [If no to 45] Is there a reason that you do not have related insurance coverage?

46. What was the approximate cost of your business damages from Hurricane Irma?

47. How did you finance your business' recovery from the event? [Please indicate with a dollar amount]

\begin{tabular}{|l|l|}
\hline Personal savings & \\
\hline Credit card & \\
\hline Corporate assistance (or assistance from another branch/location) & \\
\hline Insurance & \\
\hline Donations & \\
\hline Private bank loans & \\
\hline Crowd funding & \\
\hline Assistance from friends or family & \\
\hline $\begin{array}{l}\text { Federal assistance programs (e.g. Small Business Administration loans) } \\
\text { (List: }\end{array}$ & \\
\hline $\begin{array}{l}\text { State assistance programs (e.g. Resilient Recovery Loan Program) } \\
\text { (List: }\end{array}$ & \\
\hline
\end{tabular}




\begin{tabular}{|l|l|}
$\begin{array}{l}\text { Local assistance programs (e.g. grant or loan from the city or local non-profit) } \\
\text { (List: }\end{array}$ & \\
\hline Other: & \\
\hline Other: & \\
\hline Other: & \\
\hline TOTAL & \\
\hline
\end{tabular}

** Bridge Loan: typically, loans between $\$ 1,000$ and $\$ 50,000$ for up to one year. While the bridge loan is a source of expedient funds, it is not designed to be the primary source of assistance for affected small businesses

48. [If $47=$ "yes, to insurance"] Did you file claims and receive money?

\begin{tabular}{|l|l|l|l|l|l|l|}
\hline & $\begin{array}{l}\text { Required to } \\
\text { have } \\
\text { insurance? }\end{array}$ & $\begin{array}{l}\text { Had } \\
\text { Insurance? }\end{array}$ & Filed Claim? & $\begin{array}{l}\text { Received } \\
\text { Money? }\end{array}$ & $\begin{array}{l}\text { Received } \\
\text { When? } \\
\text { (months } \\
\text { after } \\
\text { event) }\end{array}$ & $\begin{array}{l}\text { \% } \\
\text { insurance } \\
\text { covered }\end{array}$ \\
\hline Building & $\begin{array}{l}\text { 1. Yes } \\
\text { 2. No } \\
\text { 3. D/K }\end{array}$ & $\begin{array}{l}\text { 1. Yes } \\
\text { 2. No } \\
\text { 3. D/K }\end{array}$ & $\begin{array}{l}\text { 1. Yes 2. No 3. } \\
\text { We paid for all }\end{array}$ & $\begin{array}{l}\text { 1. Yes } \\
\text { 2. No } \\
\text { 3. pending }\end{array}$ & & \\
\hline $\begin{array}{l}\text { Content } \\
\text { business } \\
\text { insurance/most } \\
\text { relevant to } \\
\text { renters) }\end{array}$ & $\begin{array}{l}\text { 1. Yes } \\
\text { 2. No }\end{array}$ & $\begin{array}{l}\text { 3. Yes } \\
\text { 3. No } \\
\text { 3. } / \mathrm{K} / \mathrm{K}\end{array}$ & $\begin{array}{l}\text { 1. Yes 2. No 3. } \\
\text { We paid for all }\end{array}$ & $\begin{array}{l}\text { 1. Yes } \\
\text { 2. No } \\
\text { 3. pending }\end{array}$ & & \\
\hline $\begin{array}{l}\text { Business } \\
\text { interruption }\end{array}$ & $\begin{array}{l}\text { 1. Yes } \\
\text { 2. No } \\
\text { 3. D/K }\end{array}$ & $\begin{array}{l}\text { 1. Yes } \\
\text { 2. No } \\
\text { 3. D/K }\end{array}$ & $\begin{array}{l}\text { 1. Yes 2. No 3. } \\
\text { We paid for all }\end{array}$ & $\begin{array}{l}\text { 1. Yes } \\
\text { 2. No } \\
\text { 3. ending }\end{array}$ & & \\
\hline
\end{tabular}

49. What assistance did you need and not get? (monetary or in-kind):

50. How long do you estimate this business could function in a deficit ( $X$ days, weeks, months)?

51. What mitigation actions have you taken since Hurricane Irma? (select all that apply) [NOTE: Please refer to Descriptions of Business Mitigation Activities document for further description]

\begin{tabular}{|c|c|c|c|c|}
\hline $\begin{array}{ll}\text { a. Business } \\
\text { Elevation }\end{array}$ & b. Landscaping & & Dry-proofing & $\begin{array}{ll}\text { d. Flood- } \\
\text { proofing }\end{array}$ \\
\hline $\begin{array}{ll}\text { e. } & \text { Have an } \\
\text { emergency plan } \\
\text { in-place }\end{array}$ & $\begin{array}{ll}\text { f. } & \text { Purchase } \\
\text { increased } \\
\text { insurance }\end{array}$ & & $\begin{array}{l}\text { Maintain } \\
\text { offsite backups }\end{array}$ & \\
\hline
\end{tabular}

52. Have there been changes in the severity and frequency of hurricanes affecting your business?

\begin{tabular}{|c|c|c|c|}
\hline $\begin{array}{l}52.1 . \\
\text { Severity (damage) }\end{array}$ & 1. Decreasing greatly 2 . Decreasing & 3. Unchanged & 4. Increasing 5. Increasing greatly \\
\hline $\begin{array}{l}52.2 . \\
\text { Frequency }\end{array}$ & 1. Decreasing greatly 2 . Decreasing & 3. Unchanged & 4. Increasing 5 . Increasing greatly \\
\hline
\end{tabular}


53. How many similar hurricanes have occurred at this location that have required your business to close temporarily (e.g., the business was inaccessible, decided to close)? names/dates)

54. Have there been changes in the severity and frequency of recurrent floods affecting your business?

\begin{tabular}{|c|c|c|c|}
\hline $\begin{array}{l}\text { 54.1. } \\
\text { Severity } \\
\text { (damage) }\end{array}$ & 1. Decreasing greatly 2 . Decreasing & 3. Unchanged & 4. Increasing 5. Increasing greatly \\
\hline $\begin{array}{l}54.2 . \\
\text { Frequency }\end{array}$ & 1. Decreasing greatly 2 . Decreasing & 3. Unchanged & 4. Increasing 5. Increasing greatly \\
\hline
\end{tabular}

54.3 How many recurrent floods has your business experienced in the last year?

54.4 How have they impacted your business (i.e. parking lot was flooded, water entered the building, could not drive to work)

55. Are there resources you've gotten from your local government that have been useful? Are there things you'd like to see provided by local government?

\section{Owner / Manager Demographics}

56. What is your age? (years)

57. What is your number of years of schooling? Enter number of years and indicate type of diploma or degree:

1. Some high school, but didn't finish

2. Completed High School

3. Some college, but didn't finish

4. Associate degree

5. Bachelors

6. Masters or higher degree

58. Are you Hispanic? 1. Yes 2. No

59. What is your race? Select one or more (check all relevant)

\begin{tabular}{|l|l|}
\hline$\circ$ White & $\circ \quad$ Asian \\
$\circ$ Black or African American & $\circ \quad$ Native Hawaiian or other Pacific Islander \\
$\circ$ American Indian or Native American & \\
\hline
\end{tabular}

60. What is your household income? (per year before taxes)

\begin{tabular}{|r|l|}
\hline e. Under $\$ 25,000$ & e. $\$ 80,000-\$ 99,999$ \\
\hline f. $\$ 25,000-\$ 39,999$ & f. $\$ 100,000-\$ 124,999$ \\
\hline g. $\$ 40,000-\$ 59,999$ & g. $\$ 125,000-\$ 149,999$ \\
\hline h. $\$ 60,000-\$ 79,999$ & h. Over $\$ 150,000$ \\
\hline
\end{tabular}


If you have any comments about the survey and/or business recovery after Hurricane Irma, please let us know verbally or write them in the space below.

\section{THANK YOU VERY MUCH FOR COMPLETING THE SURVEY!}

This collection of information contains Paperwork Reduction Act (PRA) requirements approved by the Office of Management and Budget (OMB). Notwithstanding any other provisions of the law, no person is required to respond to, nor shall any person be subject to a penalty for failure to comply with, a collection of information subject to the requirements of the PRA unless that collection of information displays a currently valid OMB control number. For this collection, the OMB Control number is:0693-0078 with an expiration date: July 31, 2019. Public reporting burden for this collection is estimated to be 15 minutes per survey, including the time for reviewing instructions, searching existing data sources, gathering and maintaining the data needed and completing and reviewing the collection of information. Send comments regarding this burden estimate or any aspect of this collection of information, including suggestions for reducing this burden, to the National Institute of Standards and Technology, Attn: Dr. Jennifer Helgeson, NIST, 100 Bureau Drive, MS 8603, Gaithersburg, MD 20899-1710, telephone 301-975-6133, or via email: jennifer.helgeson@nist.gov. 


\title{
Appendix B - Consent Script
}

\author{
Post-Hazard Event Field Study in [city, state] \\ Business Recovery Survey \\ Consent Script \\ OMB CONTROL NO. 0693-0078 Expiration date: 07/31/2022
}

Hello, my name is [interviewer name] and I am a researcher from [name of university, CISA, or National Institute of Standards and Technology] in the [department name/ Laboratory name]. We are conducting a research study on business recovery following the [natural hazard even type] that occurred in [location city, state]during [dates of event and event name].

I'd would like to speak with you about how this event affected your business or place of employment. In particular, we are interested in learning about your experience resuming normal operations after this event.

This study is part of a larger project led by [LIST entities relevant to NIST, NOAA]. Relevant contact information for each location.

We would like to ask you some brief survey questions about your business' experience after [disaster event name/type], as well as some details about your business during the time of a disaster event. Participation will take approximately fifteen to twenty minutes, Your participation is voluntary. If you decide to participate in the study, you may withdraw your consent and stop participation at any time.

We will be collecting information about the damage to this business, the repair process, and how the disaster event disrupted the business' employees, supply chain, and revenue. When we report and share our findings, we will combine the data from all participants into summary statistics and tables so no unique individual or business can be identified. There are NO KNOWN RISKS or direct benefits to you. We hope to gain more knowledge on how you and others were affected by disaster events in this area, so that we can learn from your experiences to help communities better prepare for similar events in the future.

So again, we would like to speak with an owner or manager of this business that was here at the time of [insert event name] OR someone who knows about what happened to the business around that time. Would that person be you? And are you willing to participate?

This collection of information contains Paperwork Reduction Act (PRA) requirements approved by the Office of Management and Budget (OMB). Notwithstanding any other provisions of the law, no person is required to respond to, nor shall any person be subject to a penalty for failure to comply with, a collection of information subject to the requirements of the PRA unless that collection of information displays a currently valid OMB control number. For this collection, the OMB Control number is: 0693-0078 with an expiration date: July 31, 2019. Public reporting burden for this collection is estimated to be 15 minutes per survey, including the time for 
reviewing instructions, searching existing data sources, gathering and maintaining the data needed and completing and reviewing the collection of information. Send comments regarding this burden estimate or any aspect of this collection of information, including suggestions for reducing this burden, to the National Institute of Standards and Technology, Attn: Dr. Jennifer Helgeson, NIST, 100 Bureau Drive, MS 8603, Gaithersburg, MD 20899-1710, telephone 301-9756133, or via email:jennifer.helgeson@nist.gov. 


\section{Appendix C - Descriptions of Business Damage States}

\begin{tabular}{|c|c|c|c|c|c|c|}
\hline & Description & DSO & DS1 & DS2 & DS3 & DS4 \\
\hline Buildings & $\begin{array}{l}\text { Business } \\
\text { building/ } \\
\text { structural } \\
\text { damage }\end{array}$ & $\begin{array}{l}\text { No damage; No } \\
\text { contact to } \\
\text { electrical or } \\
\text { plumbing, etc. } \\
\text { in crawlspace. } \\
\text { No contact with } \\
\text { floor joists. No } \\
\text { sewer backup }\end{array}$ & $\begin{array}{l}\text { Water touches floor joists up } \\
\text { to minor water enters } \\
\text { building; damage to carpets, } \\
\text { pads, baseboards, flooring. } \\
\text { Approximately } 1^{\prime \prime} \text { in the } \\
\text { building but no drywall } \\
\text { damage. Could have some } \\
\text { mold in crawlspace. Could } \\
\text { have minor sewer backup } \\
\text { and/or minor mold issues. }\end{array}$ & $\begin{array}{l}\text { Water level approximately } 2 \\
\text { feet with associated drywall } \\
\text { damage and electrical } \\
\text { damage, water heater and } \\
\text { other major equipment. } \\
\text { Doors or windows may need } \\
\text { replacement. Could have } \\
\text { major sewer backup and /or } \\
\text { major mold issues. }\end{array}$ & $\begin{array}{l}\text { Water level } 2 \text { feet to } 8 \text { feet; } \\
\text { substantial drywall damage, } \\
\text { electrical panel destroyed, } \\
\text { office cabinets or storage } \\
\text { racks; lighting fixtures on } \\
\text { walls destroyed; ceiling } \\
\text { lighting may be ok. Studs } \\
\text { reusable; some may be } \\
\text { damaged. Could have major } \\
\text { sewer backup and/or major } \\
\text { mold issues. }\end{array}$ & $\begin{array}{l}\text { Significant structural } \\
\text { damage present; all } \\
\text { drywall, cabinets etc. } \\
\text { destroyed. Could be } \\
\text { floated off foundation. } \\
\text { Building must be } \\
\text { demolished or potentially } \\
\text { replaced. }\end{array}$ \\
\hline \multirow{2}{*}{$\begin{array}{l}\text { Content/ } \\
\text { Inventory }\end{array}$} & Physical & No damage & $\begin{array}{l}\text { All reusable/usable easily } \\
\text { once dried, with zero or slight } \\
\text { value drop }\end{array}$ & $\begin{array}{l}\text { About } 60 \% \text { reusable with } \\
\text { drying and cleaning, and } \\
\text { moderate value drop }\end{array}$ & $\begin{array}{l}\text { About } 30 \% \text { reusable with } \\
\text { drying and cleaning, and } \\
\text { significant value drop }\end{array}$ & $\begin{array}{l}\text { Non-reusable once dried } \\
\text { and total loss }\end{array}$ \\
\hline & $\begin{array}{l}\text { Virtual (Data/ } \\
\text { Information, } \\
\text { etc.) }\end{array}$ & No damage & All recoverable easily & About $60 \%$ recoverable & About $30 \%$ recoverable & Non-recoverable \\
\hline \multirow{2}{*}{$\begin{array}{l}\text { Machinery/ } \\
\text { Equipment }\end{array}$} & Singular & No damage & $\begin{array}{l}\text { Operational easily once dried, } \\
\text { with zero or slight value drop }\end{array}$ & $\begin{array}{l}\text { Partially operational at } 60 \% \\
\text { capacity after drying and } \\
\text { cleaning, and replacement of } \\
\text { parts. Moderate value drop }\end{array}$ & $\begin{array}{l}\text { Partially operational at } 30 \% \\
\text { capacity after drying and } \\
\text { cleaning, and replacement of } \\
\text { parts. Significant value drop }\end{array}$ & $\begin{array}{l}\text { Non-operational, full } \\
\text { replacement is required }\end{array}$ \\
\hline & Inter-reliant & No damage & $\begin{array}{l}\text { All operational easily once } \\
\text { dried, with zero or slight value } \\
\text { drop }\end{array}$ & $\begin{array}{l}\text { About } 60 \% \text { operational after } \\
\text { drying and cleaning, with } \\
\text { moderate value drop }\end{array}$ & $\begin{array}{l}\text { About } 30 \% \text { operational after } \\
\text { drying and cleaning, with } \\
\text { significant value drop }\end{array}$ & $\begin{array}{l}\text { Non-operational, full } \\
\text { replacement and inter- } \\
\text { reliant operating process } \\
\text { are required }\end{array}$ \\
\hline
\end{tabular}

Table 2. Detailed damage descriptions for business building components (Xiao et al., 2020) 


\section{Appendix D - Descriptions of Business Mitigation Activities - categories and sub-categories}

\section{Field Study}

\section{Business Damage Survey}

(based on FEMA Recommendations https://www.wbdq.org/FFC/DHS/femap936.pdf)

Five generalized mitigation categories with constituent sub-categories

\section{Home elevation}

- Elevate on fill

- Elevate on pilings, posts, piers or walls

\section{Landscaping}

- Building permanent floodwalls

- Installing levees to block incoming water

- Create positive grade flow away from the building

- Install retention pond

- Installing French drains

- Installing pervious pavement

\section{Dry-proofing (i.e., trying to keep all water out)}

- Create continuous impermeable walls, coated with waterproofing compounds or plastic sheeting

- Sealants for openings such as doors, windows, sewer lines, and vents

- Shields for openings such as doors, windows, sewer lines, and vents

- Purchase movable floodwalls

- Install backflow valves to avoid sewer backup

- Dry proof a section of the building

- Have an internal drainage system for seepage in sump pumps 
4. Flood-proofing (wet) (i.e., reduces damage if water gets in)

NOTE: A wet-proofed building intentionally allows floodwaters into the building to minimize water pressure on the structure. As a result, the loads imposed on the house during a flood, and therefore the likelihood of structural damage, may be reduced greatly.

- Elevate electric outlets

- Elevate electric breaker box

- Elevate water heater/water utilities

- Elevate natural gas utilities

- Elevate septic

- Elevate other appliances (e.g., washer, drier, freezer)

- Elevate mechanical systems (e.g., airducts)

- Elevate HVAC

- Add shelving (e.g., cinder blocks) to raise goods off of the floor by some amount

- Arrange for second-floor storage

\section{Have an emergency plan in place for temporary installations (e.g., flood shields)}

\section{Purchase insurance}

\section{Maintain offsite backups}




\section{Appendix E - Business Communication Tracking}

\begin{tabular}{|l|l|l|l|l|l|l|l|l|l|}
\hline PIN & $\begin{array}{l}\text { Location } \\
\text { Zone }\end{array}$ & Survey Code* & $\begin{array}{l}\text { Date } \\
\text { Contacted } \\
\text { (Follow } \\
\text { up dates) }\end{array}$ & $\begin{array}{l}\text { Hours of } \\
\text { Operation }\end{array}$ & $\begin{array}{l}\text { Company } \\
\text { Name }\end{array}$ & $\begin{array}{l}\text { Street } \\
\text { Address }\end{array}$ & $\begin{array}{l}\text { Name of } \\
\text { contact }\end{array}$ & $\begin{array}{l}\text { Phone } \\
\text { number of } \\
\text { contact }\end{array}$ & \begin{tabular}{l} 
Notes \\
\hline
\end{tabular} \\
\hline
\end{tabular}

(1=complete, 0 =ineligible (no owner/manager), $3=$ wrong address, could not locate, $4=$ hard refusal, $5=$ soft refusal, set a future time to interview, $6=$ soft refusal, left form, $7=$ incomplete survey, $8=$ Closed BEFORE event, $9=$ Close AFTER event/destroyed, $10=$ no answer, is operating, 11=no access (fence/private entry), 12=ineligible, business different than expected 


\section{References}

Aldrich, H.E. and E.R. Auster. (1985). Even Dwarfs Started Small: Liabilities of Age and Size and Their Strategic Implications. Research in Organizational Behavior 8:165198.

Alesch, D. J., J.N. Holly, E. Mittler, and R. Nagy. (2001). Organizations at Risk: What Happens When Small Businesses and Not-for-Profits Encounter Natural Disasters (p. 116). Public Entity Risk Institute.

American Society of Civil Engineers (ASCE). 2014. "Seismic Evaluation and Retrofit of Existing Buildings." Reston, VA.

American Society of Civil Engineers (ASCE). 2016. "Minimum Design Loads and Associated Criteria for Buildings and Other 1082 Structures." Reston, VA.

Asgary, A., M.I. Anjum, and N. Azimi. (2012). Disaster recovery and business continuity after the 2010 flood in Pakistan: Case of small businesses. International Journal of Disaster Risk Reduction, 2, 46-56. https://doi.org/10.1016/j.ijdrr.2012.08.001

Augier, M. and D.J. Teece,. (2009). Dynamic Capabilities and the Role of Managers in Business Strategy and Economic Performance. Organization Science, 20(2), 410421. https://doi.org/10.1287/orsc. 1090.0424

Barman, S. D., S. C. Majumder and S. Sarker (2012). "Effecting Factors of Disaster Loss Recovery Plan (DLRP) for Small Scale Business (SCB) in the Coastal Area of Bangladesh." Iğdır Univ J Inst Sci \& Tech 2(4): 67-72.

Bartik, A.W., M. Bertrand, Z. Cullen, E.L. Glaeser, M. Luca, and C. Stanton. (2020). "The impact of COVID-19 on small business outcomes and expectations." PNAS July 28, 2020117 (30) 17656-17666; https://doi.org/10.1073/pnas.2006991117

Basker, E., and J. Miranda. (2012). Taken by Storm: Business Survival in the Aftermath of Hurricane Katrina.

Blanchard, T. C., Tolbert, C., and C. Mencken. (2012). The health and wealth of US counties: How the small business environment impacts alternative measures of development. Cambridge Journal of Regions, Economy and Society, 5(1), 149-162. https://doi.org/10.1093/cjres/rsr034

Cavanaugh, M. L. (2000). The Loma Prieta Earthquake and Hurricane Andrew: a comparative study of disaster preparedness activities. M. A. Thesis. Newark, DE: Department of Sociology and Criminal Justice, University of Delaware.

Chang, S.E. (2010). "Urban disaster recovery: a measurement framework and its application to the 1995 Kobe earthquake.” Disasters. Vol. 34, Issue 2. April 2010. Pp. 303-327. 
Chang, S. E., and A. Falit-Baiamonte. (2002). Disaster vulnerability of businesses in the 2001 Nisqually earthquake. Environmental Hazards, 4(2), 59-71. https://doi.org/10.3763/ehaz.2002.0406

Chang, S. and A. Rose. (2012). "Economic Recovery to Disasters." International journal of mass emergencies and disasters 30(2):171-181.

Clarke, L., M. Hejazi, J. Horing, A.C. Janetos, K. Mach, M. Mastrandrea, K. Lee, M. Orr, B.L. Preston, P. Reed, R.D. Sands, and D.D. White. "Sector Interactions, Multiple Stressors, and Complex Systems," in Impacts, Risks, and Adaptation in the United States: Fourth National Climate Assessment, Volume II K. Lee (ed.) Accessible at: https://nca2018.globalchange.gov/chapter/complex-systems.

Corey, C. M. and E. A. Deitch (2011). "Factors affecting business recovery immediately after Hurricane Katrina." Journal of Contingencies and crisis management 19(3): 169-181.

Dahlhamer, J. M. and M.J. D’Souza. (1995). Determinants of business disaster preparedness in two US metropolitan areas. International Journal of Mass Emergencies and Disasters, 15(2), 265-281.

Dahlhamer, J. M. and K. J. Tierney (1998). "Rebounding from disruptive events: Business recovery following the Northridge earthquake." Sociological Spectrum 18(2): 121141.

Dash, N., B. H. Morrow, J. Mainster and L. Cunningham (2007). "Lasting effects of Hurricane Andrew on a working-class community." Natural Hazards Review 8(1): $13-21$.

Eggers, F. (2020). "Masters of disasters? Challenges and opportunities for SMEs in times of crisis." Journal of Business Research. Vol. 116, Aug. 2020, Pp 199-208. https://www.sciencedirect.com/science/article/pii/S0148296320303222

Enarson, E. (2010). Gender, CRC Press, Boca Raton, FL: 123-154.

Fanta, V., M. Šálek, and P. Sklenicka. (2019). How long do floods throughout the millennium remain in the collective memory? Nature Communications, 10(1), 1105. https://doi.org/10.1038/s41467-019-09102-3

Fort, T. C., J. Haltiwanger, R. S. Jarmin and J. Miranda (2013). "How firms respond to business cycles: The role of firm age and firm size." IMF Economic Review 61(3): 520-559. 
Grinyer, P. H., and J.C. Spender. (1979). Recipes, Crises, and Adaptation in Mature Businesses. International Studies of Management \& Organization, 9(3), 113-133. JSTOR.

Haynes, G. W., S.M. Danes, H.L. Schrank, and Y. Lee. (2019, June 1). Survival and success of family-owned small businesses after hurricane Katrina: Impact of disaster assistance and adaptive capacity. Journal of Contingencies and Crisis Management. https://doi.org/10.1111/1468-5973.12245

Helgeson, J., J. Fung, Y. Zhang, A.R. Roa Henriquez, A. Zycherman, C. Nierenberg, D. Butry, D. Ramkissoon. (2020). Eliciting lessons from small- and medium-sized enterprises (SMEs) for natural disaster resilience planning and recovery during the COVID-19 pandemic: SME Complex Event Resilience, NIST DCI 002, Gaithersburg, MD. https:doi.org/106028/NIST.DCI002.

Hillier, J.K., T. Matthews, R.L. Wilby, and C. Murphy. Multi-hazard dependencies can increase or decrease risk. Nat. Clim. Chang. 10, 595-598 (2020). https://doi.org/10.1038/s41558-020-0832-y

InfoGroup Inc. (2018). U.S. Historical Businesses: All businesses in Charleston, SC in year 2018 [Data file]. Retrieved from http://referenceusa.com/UsHistoricalBusiness

Kroll, C., J. Landis, and Q. Shen, (1991). Economic Impacts of the Loma Prieta Earthquake: A Focus on Small Business. Center for Real Estate and Urban Economics, 91-187. https://cloudfront.escholarship.org/dist/prd/content/qt8kz940rs/qt8kz940rs.pdf

Lam, N.S.N., H. Arenas, K. Pace, J. LeSage, R. Campanella. (2012). "Predictors of Business Return in New Orleans after Hurricane Katrina.” PLoS ONE 7(10): e47935. https://doi.org/10.1371/journal.pone.0047935

LeSage, J.P., R.K. Pace, N. Lam, R. Campanella, and X. Liu (2011). New Orleans business recovery in the aftermath of Hurricane Karins. Journal of the Royal Statistical Society: A Series (Statistics in Society), 174(4), 1007-27.

Levine, N. S. and L. Agudelo. (2019) Hurricane Irma Storm Surge Charleston County, South Carolina, Online Webmap. The Lowcountry Hazards Center, Charleston SC, Accessed 9/14/2020 https://scgis.maps.arcgis.com/home/webmap/viewer.html?useExisting=1\& layers $=$ ef $2560 \mathrm{~d} 877644828 \mathrm{bb} 164 \mathrm{bc} 9 \mathrm{bc} 3 \mathrm{bf} 38 \mathrm{c}$

Lyson, T. A., R.J. Torres, and R. Welsh. (2001). Scale of Agricultural Production, Civic Engagement, and Community Welfare. Social Forces, 80(1), 311-327. https://doi.org/10.1353/sof.2001.0079

Marshall M.I. and H.L. Schrank. (2014). Small business disaster recovery: a research framework. Nat Hazards 72:597-616. 
Marshall, M. I., L.S. Niehm, S.B. Sydnor, and H.L. Schrank, (2015). Predicting small business demise after a natural disaster: An analysis of pre-existing conditions. Natural Hazards, 79(1), 331-354. https://doi.org/10.1007/s11069-015-1845-0

Meeks, A. (2019). "Accounting for Disaster: Small Business Recovery in North Carolina after Hurricanes Matthew and Florence." Department of Urban Studies and Planning in Partial Fulfillment of the Requirements of the Degree of Master in City Planning. Massachusetts Institute of Technology. https://dspace.mit.edu/bitstream/handle/1721.1/123974/1140509310MIT.pdf?sequence $=1 \&$ isAllowed $=y$

Morrison, A., J. Breen, and S. Ali. (2003, October 1). Small Business Growth: Intention, Ability, and Opportunity. Journal of Small Business Management. https://doi.org/10.1111/1540-627X.00092

Moving beyond isolated events. Nat. Clim. Chang. 10, 583 (2020). https://doi.org/10.1038/s41558-020-0846-5

National Weather Service. (2019). Hurricane Dorian-September 4-5, 2019. Weather.Gov. https://www.weather.gov/chs/HurricaneDorian-Sep2019

National Weather Service, N. (2017). Tropical Storm Irma-September 10-11, 2017.

Niehm, L. S., J. Swinney, and N.J. Miller, (2008). Community Social Responsibility and Its Consequences for Family Business Performance. Journal of Small Business Management, 46(3), 331-350. https://doi.org/10.1111/j.1540-627X.2008.00247.x

NOAA. (2017). "Extremely active 2017 Atlantic hurricane season finally ends." Available at: https://www.noaa.gov/media-release/extremely-active-2017-atlantic-hurricaneseason-finally-ends.

NOAA. (2019). NOAA. Hurricane Fast Facts. Available at: https://coast.noaa.gov/states/fast-facts/hurricane-costs.html.

Phillips, C.A., A. Caldas, R. Cleetus, K. A. Dahl, J. Declet-Barreto, R. Licker, L.D. Merner, J. P. Ortiz-Partida, A.L. Phelan, E. Spanger-Siegfried, S. Talati, C.H. Trisos and C.J. Carlson. (2020). "Compound climate risks in the COVID-19 pandemic." Nat. Clim. Chang. 10, 586-588 https://doi.org/10.1038/s41558-020-0804-2.

Raymond, C., R.M. Horton, J. Zscheischler, O. Martiua, A. AghaKouchak, J. Balch, S.G. Bowen, S.J. Camargo, J. Hess, K. Kornhuber, M. Oppenheimer, A.C. Ruane, T. Wahl, and K. White. Understanding and managing connected extreme events. Nat. Clim. Chang. 10, 611-621 (2020). https://doi.org/10.1038/s41558-020-0790-4 
Runyan, R. C. (2006). Small Business in the Face of Crisis: Identifying Barriers to Recovery from a Natural Disaster1. Journal of Contingencies and Crisis Management, 14(1), 12-26. https://doi.org/10.1111/j.1468-5973.2006.00477.

Small Business Administration. (2019). 2019 small business profile. SBA's Office of Advocacy. https://cdn.advocacy.sba.gov/wpcontent/uploads/2019/04/23142719/2019-Small-Business-Profiles-US.pdf

Schaer, C., N. Kuruppu, and UNEP DTU Partnership. (2018). Private-sector action in adaptation: Perspectives on the role of micro, small and medium size enterprises. UNEP DTU Partnership.

Schindehutte, M., and M.H. Morris. (2001). Understanding strategic adaptation in small firms. International Journal of Entrepreneurial Behavior \& Research, 7(3), 84-107. https://doi.org/10.1108/EUM0000000005532

Schrank, H. L., Marshall, M. I., Hall-Phillips, A., Wiatt, R. F., and Jones, N. E. (2013). Small-business demise and recovery after Katrina: Rate of survival and demise. Natural Hazards, 65(3), 2353-2374. https://doi.org/10.1007/s11069-012-0480-2

Tierney, K. J., and G.R. Webb (2001), "Business Vulnerability to Earthquakes and Other Disasters", University of Delaware Disaster Research Center, Preliminary Paper Nr. 320.

Tierney, K. J. (1997). Business Impacts of the Northridge Earthquake. Journal of Contingencies and Crisis Management, 5(2), 87-97. https://doi.org/10.1111/1468$\underline{5973.00040}$

Tierney, K. J. (2007). Businesses and disasters: vulnerability, impacts, and recovery. Handbook of disaster research, Springer: 275-296.

Tolbert, C. M., Lyson, A., and Irwin, M. D. (1998). Local Capitalism, Civic Engagement, and Socioeconomic Well-Being. 27.

Watson, M., Y. Xiao, J. Helgeson, and M. Dillard. (2020). "Importance of Households in Business Disaster Recovery." Nat. Hazards Rev. 2020, 21, 05020008.

Webb, G. R., K.J. Tierney, and J.M. Dahlhamer. (2002). Predicting long-term business recovery from disaster: A comparison of the Loma Prieta earthquake and Hurricane Andrew. Environmental Hazards, 4(2), 45-58. https://doi.org/10.3763/ehaz.2002.0405

Wasileski, G., H. Rodríguez, and W. Diaz. (2011). Business closure and relocation: A comparative analysis of the Loma Prieta earthquake and Hurricane Andrew. Disasters, 35(1), 102-129. https://doi.org/10.1111/j.1467-7717.2010.01195.x 
Xiao, Y. and J. Drucker (2013). "Does Economic Diversity Enhance Regional Disaster Resilience?," Journal of the American Planning Association, 79:2, 148-160.

Xiao, Y., M. Watson, J. Helgeson, K. Farokhnia, J. van de Lindt, J. Mitrani-Reiser, E. Sutley, D. Deniz, T. Tomiczek, A. Barbosa, J. Fung, O. Nofal, and M. Koliou. (2020). "Business Survey Instrument, January 19, 2018: Wave 2", in A Longitudinal Community Resilience Focused Technical Investigation of the Lumberton, North Carolina Flood of 2016. DesignSafe-CI. https://doi.org/10.17603/ds2-f9kt-fm93.

Xiao, Y. and S. Van Zandt. (2012). Building community resiliency: Spatial links between household and business post-disaster return. Urban Studies, 49(11): 2523-2542.

Zhang, Y., M.K. Lindell, and C.S. Prater. (2009). Vulnerability of community businesses to environmental disasters. Disasters, 33(1), 38-57. https://doi.org/10.1111/j.14677717.2008.01061.x

Zolin, R., and F. Kropp. (2007). How surviving businesses respond during and after a major disaster. Journal of Business Continuity, l(2), 18. 